\title{
Financial and Economic Health in European Member States: A Rational Management Theory
}

\author{
Alessandro Migliavacca ${ }^{1} \&$ Christian Rainero ${ }^{1}$ \\ ${ }^{1}$ University of Turin, Italy \\ Correspondence: Alessandro Migliavacca, University of Turin, Italy. E-mail: amigliav@unito.it
}

Received: December 15, 2016

Accepted: February 20, 2017

Online Published: March 26, 2017

doi:10.5539/ijbm.v12n4p34

URL: https://doi.org/10.5539/ijbm.v12n4p34

\begin{abstract}
The last decades of the European Union have been sprinkled of several instability problems, fluctuating between the growth of some State and crises of some other, without reaching an economic stability unity. Even in the presence of the Stability and Growth Pact (SGP) agreement, most of the States failed to monitor their health and gradually achieve positive results in term of Sovereign Debt exposure, economic growth and population's happiness and satisfaction. According to the Rational Management Theory, any organization (both private or public, whatever the dimension) can be managed through three specific "rational" macro-phases. A first phase is called "Planning". In this phase, all the initiatives and actions are forecasted, planned and defined coherently with the vision, the mission, the target and the budget of the organization. In the second phase, named "Execution", those actions are implemented and performed. In the third phase, titled "Controlling", is conducted a gap analysis between the deliverable and the achieved performance, therefore corrective actions can be proposed and implemented. The three phases are cyclic and backed by several documents, in particular budgeting statements and reports, accountancy and final balance statement. In this framework, the European Union members can find a map to a better managerial system, even taking into account all the complexity that characterizes a State. To evaluate the financial and economic health gauge of European Union Member States, we propose to verify if some of the most acknowledged managerial tools of financial statement interpretation can provide some gauges for economic and financial health and even predict or enhance the Deficit/GDP Ratio and the other structural ratios of the SGP. The sample is extracted from the European Central Bank Statistical Warehouse, analyzing some of the most critical accounts for the General Governments and comparing them with the most famous structural financial stability measures. The comparison will be conducted on the panel of most of the EU Member States financial and economic data for the last two decades. This contribution intends to foster the improvement and development of a set of supplementary instruments for a better management based on accounting data and strengthened by the European System of Accounts (2010 version).
\end{abstract}

Keywords: economic health, European Union, financial statement, rational management theory, stability growth pact

\section{Introduction}

During the last decades in European Union, several problems concerning the financial, economic and social instability rose up. A fluctuation between outstanding growth in some State and severe crises of others characterized in particular the first fifteen years of the New Millennium. Despite of the monetary and economic union, the stability has never been reached, even in the presence of the Stability and Growth Pact (SGP).

Most of the Countries continuously failed in monitoring their financial health and in gradually achieving positive results in term of Sovereign Debt exposure, economic growth and population's happiness and satisfaction. In this situation of instability, several limitations have been set and the bar has been raised more and more, in particular for those of the Countries that faced the most severe crises. The high restrictions level and the conjuncture mixed effect caused the population to pay for past errors due to a bad public money management. In this contribution we propose to verify if some of the most acknowledged managerial tools of financial statement interpretation (e.g. Current Ratio, Leverage, and similar instruments derived from financial statement data), after an adaptation, can provide some gauges for economic and financial health and even predict or enhance the Deficit/GDP Ratio and the other structural ratios of the SGP.

The sample has been extracted from the European Central Bank Statistical Warehouse, analyzing some of the most 
critical accounts for the General Governments and comparing them with the most famous structural financial stability measures. The comparison will be conducted on the panel of some representative of the EU Member States financial and economic data for the last two decades.

The intention of this contribution is to foster the improvement and development of a supplementary set of managerial instruments for a better policy making based on accounting data, strengthened by the mandatory implementation of the European System of Accounts in its 2010 version("ESA 2010 - Overview - EUROSTAT" 2016).

Section 2 describes the Stability and Growth Pact and its criticalities and introduces to Rational Management Theory based on financial statements, section 3 outlines the ESA2010 framework, section 4 defines sample and methodology, section 5 analyzes data by the means of the proposed model, section 6 concludes.

\section{A Rational Management Theory (RMT) and Public Policies}

\subsection{Stability and Growth Pact: a policy from the EU for the Member States Community Enhancement}

The Stability and Growth Pact (SGP) is an agreement pledged by the European Union members in 1997 that fixes standards and thresholds to the public expenditure policies, auditing and control. It fosters the enforcement to the requirements of the 1992 Maastricht treaty by the member states, in order to achieve a stronger integration of the market and economic substrate in the Euro zone. Referring to articles 99 and 104 of the Treaty of Rome, establishing the European Economic Community, it implements a reinforcement of the Deficit and Public Debt watch policies and an infringement procedure for the excessive deficit situations.

In particular, it sets the maximum deficit of a member state at 3 percent points of the Gross Domestic Product (GDP) and the maximum stock of sovereign debt at 60 percent of the GDP. In the case of threshold overrun, the European Union should send a first early warning to the member state or an actual reprimand. The member state can counter to the warning, suspending temporarily the procedure; in case of inactivity, the member state will be fined.

This implies that the member states should achieve and maintain a budgetary position 'close to balance or in surplus' in the medium term. In order to comply with these rules, the member state must follow a strict fiscal discipline, providing the necessary space to automatic stabilizers.

The SGP has been criticized by several authors, both academics and professionals (Beetsma and Uhlig 1999; Buti 2007; Buti, Eijffinger, and Franco 2003; Buti, Franco, and Ongena 1997; Haan et al. 2003; Schuknecht et al. 2011), since it causes to reduce financial disposal for investment and growth policies and generates conflict of interest in the member states. The criticisms of the SGP can be overtook by enhancing the transparency of the balance sheet data and accounting of the member states and using more efficient and alternative financial sustainability analysis tools.

\subsection{Rational Management Theory}

The management of any organization, whether it is private or public, small or big, profit oriented or not for profit, is conceived through a complex process of continuous implementation of decisions and policies. Each of the single decision is built up through a sub-process, that has been also called Rational Management based on financial statements(Puddu 2008; Puddu 2010; Puddu 2011) that can be divided in three separate macro phases.

In the first phase the decision is conceived on the basis of perspective and retrospective data, by means of financial and non-financial resources allocation forecast. This phase, called of Planning, is particularly important in order to define, broadly speaking, the vision and the mission of the organization and, more specifically, defining the target and the related budget (Bhushan \& Rai 2007). In the public sector management, in particular, in this phase the policy makers attempt to enhance the accountability of the decision makers and operators, and lays the foundations for any resource consumption. In particular, none of the resources that is not allotted can be consumed, and each consumption must correspond to an authorization(Potter and Diamond 1999). In order to achieve this accountability and the capability of authorization, a perspective financial statement (or budget) must be generated. In this financial statement any resource allocation is indicated and defines the maximum resources that can be used for the organization management.

The second macro phase, that naturally follows the planning one, consists in the execution of the forecasted activities. This phase, called of Execution, is founded on the budget allocations and is composed of a continuous process of unitary decisions that must generate continuous recording for actual resources consumption. The orderly, continuous and thorough recording is called accounting and permits to generate timely, precise and effective data prospectuses to enhance further decisions and gap analyses. In particular, several accounting systems 
have been created and developed for the public sector, and almost all of them lay their foundations on the double entry accounting system of financial, economic data recorded on accrual basis (even if some of the actually applied systems are still only financial-data-driven and on cash basis). The use of a shared accounting system can enhance the decision making, the stakeholder-driven disclosure and the comprehensibility of the organization's activity, namely leading to a lower information asymmetry level and allowing other organization to generate synergies through linked policies.

The third step of decision making is represented by a phase of Controlling. In this phase, any organization must take under consideration what the budget forecasted and conduct gap analyses on the deliverables expected from the budget statement with the actual execution results recorded in accounting. This phase, generally crucial for the private sector and its stakeholders' information requirements, is way less considered in the public sector, despite being it really important for a better decision making and proper accountability of the policymakers. The control phase generally exploits financial statement and accounting prospectus to achieve better comprehension of what caused differences between the forecasted and the actual performance of the organization.

A Rational management based on financial statements acknowledges the three phases and the related documentation to be produced for accountability and better policymaking in a circular vision, and is repeated on the whole at least yearly. This process enhances the potential efficiency and effectiveness of an organization and contributes to the creation of a clearer map of the actual value generation through the organization's activity. Thus, a rational management is always focused on People and their requirements (Puddu 2010) and the value generation can be considered both under the economic/financial dimension and the non-financial one, in order to maximize all the results and meet all the stakeholders' requirements and needs.

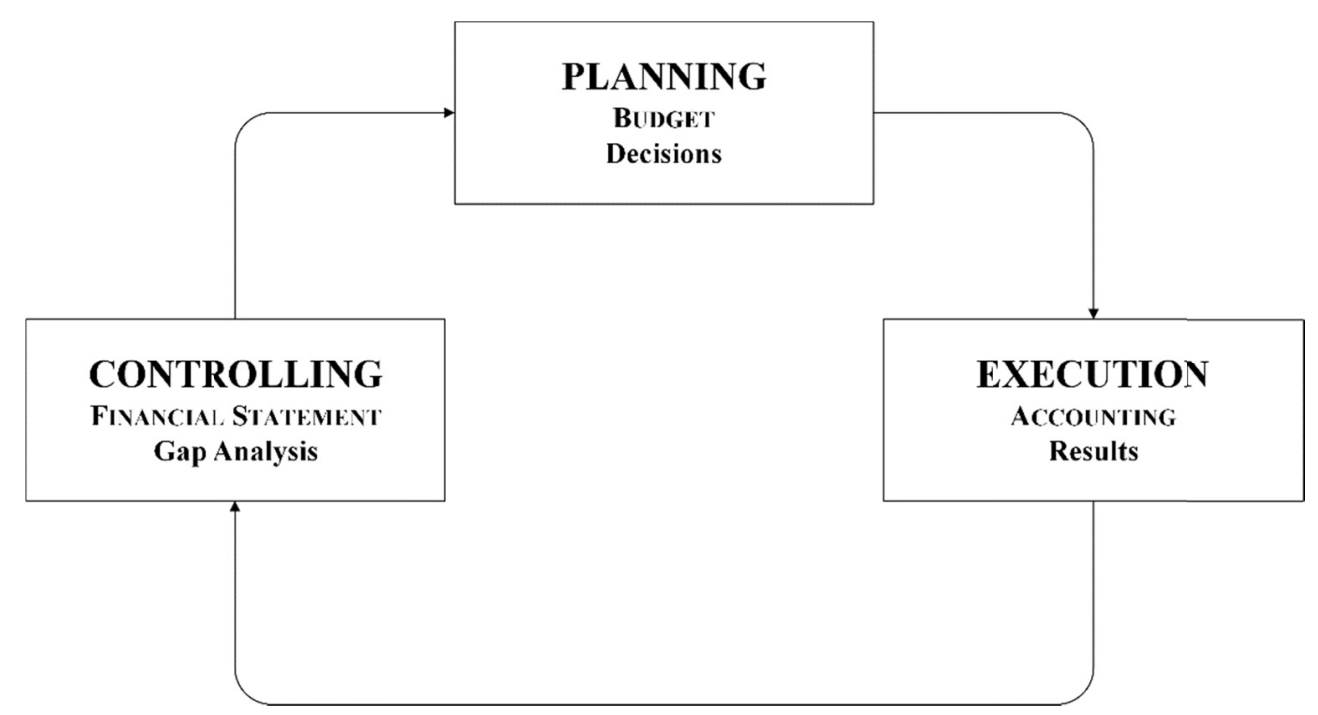

Figure 1. RMT cycle - source: our adaptation (from Puddu 2008)

\subsection{SGP and RMT: Two Acronyms, Two Paths}

In this theoretical framework of threefold subdivision of the management, the implementation of the SGP thresholds is conducive of a profound influence on the policies of the member states. As seen, the European Union is capable of penalizing a Country by the means of a single ratio based on only two "bottom-lines", which are the GDP and the Deficit, without any regard to expansive and positive long-term impact policies. In particular, it occurs because the focus of the European Union is concentrated only on the third phase of the Rational Management, the Controlling's one. This signifies to analyze only a final result, which is influenced by a great number of policies in plenty of sectors and subjects, overlooking to other two similarly important moments of the decisional process.

By this perspective, the Stability and Growth Pact measures ought not to be the one and only gauge of the financial health of a Nation, but it is necessary to find some alternative solutions to manage wealth and wellness in the member States, to conduce to a better, and synergic, growth. 


\section{The European System of Accounts (ESA 2010)}

\subsection{Introduction}

The European System of Accounts (ESA 2010) is an accounting methodology for National and Regional Accounting (EUROSTAT 2016). It consists of a coherent ensemble of accounts that proposes a quantitative and monetary description of the economic activity. It is a useful support for the structural and dynamic characteristics of an economic system such as a Nation, and it fulfills the requirements of forecasting, monitoring and analysis for the policy makers and the economic politics. The system is based on a series of identity (one-to-one) relations. Each member of the relation can be considered as the section of an account for financial incomes, outflow, revenues and expenditures through schemes that trace the enterprises system of accounts. This identity is also recognizable as a double entry accounting system.

The main purpose of the ESA is to classify the complex economic activity of a National organization and summarize it in a close number of fundamental categories and report it in a consistent macroeconomic framework.

The ESA identifies:

- The economic institutional units and their groupings;

- The operations of sectors and branches and the related economic flows and stocks.

- A system of accounts for the flows and stock variations, including

- Current operations accounts;

- Assets account

- A framework for the interdependencies between institutional units, by the means of three input-output tables.

Each unit of each sector performs operations that are conducive of income creation, allocation, redistribution and consumption. The accounts for current operations balance with the public savings, that are the primary source of accumulation. Other accounts record the variations that intervene into the assets and liabilities of the State and of each sector and conduce to the measurement of the National equity, that is structured in sub-accounts.

The input-output tables analyze the relations between the different economic sectors (or their aggregates), providing a thorough description of the resources production and consumption processes and the related financial flows generation.

\subsection{Operators}

The operators are those institutional units that have - or are capable of having - a complete system of accounting and have decisional autonomy for their main activity. The ESA groups them in five institutional sectors on the basis of the main qualities of the activity, in order to describe the income, expenditure and financial flows and the equity variations. The first category is represented by non-financial corporations and quasi-corporations, that produce goods and services for sale. A second category is composed by the financial corporations (banks and insurance), namely the intermediaries in finance and insurance. Both of these two categories are profit and equity-accumulation oriented. A third category includes the public administration and general government, that produces mainly services not intended for sale (e.g. public utilities), redistribute the National income and wealth (through fiscal policies) and contribute to the collective consumption and accumulation. A fourth category includes the private social institutions devoted to families (parties, labor unions, religious organizations, cultural and sports associations, philanthropy and caring institutions), that produce services not intended for sale but for private consumption. The fifth and last category includes families and households, that consume goods and services produced by the other sectors, but can also produce (enterprises) and accumulate equity. The ESA provides also a definition for the homogeneous productive unities, that are groupings of similar activities based on a shared European nomenclature (NACE) in order to describe the production process and allow input-output analyses.

A further distinction is given between the resident and non-resident operators, depending on whether they have their center-of-interest in the economic territory of the Nation, or of the Union, or not.

\subsection{Flows and Stocks}

The accounting system of the ESA is organized in two accounting dimensions: the former are the flows, which are the (financial) effects of a series of events in a period of time; the latter are the stocks, which are the dimension of an account (asset or liabilities) at a given point of time (generally speaking, at the start or at the end of the accounting period). 
The flows have a threefold origin:

- $\quad$ production and destination of goods and services;

- operations on distribution and redistribution of income and wealth;

- financial asset acquisitions and divestitures;

plus, a residual category for those operations that are not related to the previous (depreciations, non-produced financial assets exchanges). Each operation can have a counterpart or not; in the first case, for each cash or good/service flow there is an offset flow of the same amount; in the second case (e.g. pension and welfare payments) there is not a direct offset: those operations are called "transfers".

The stocks are classified into:

- $\quad$ produced non-financial assets: tangibles, intangibles, inventories and valuables;

- $\quad$ non-produced non-financial assets: tangibles (such as land plots, mines, hydrogeological resources, and more in general natural resources), and intangibles (goodwill, patents, leases, and so on);

- financial assets: gold, currencies, deposits, shares, bonds, loans, insurances, etc.

\subsection{Sequence of Accounts}

The ESA 2010 sequence of accounts is divided into macro categories. The first macro-category is composed by the current accounts. This macro category includes

- The "production" account, which shows the transactions relating to the production process;

- The "distribution and use of income" accounts, to analyze the primary distribution, the generation of income, the allocation of primary income and the redistribution in kind or use of the income, and includes:

○ The "primary distribution of income" account;

- The "generation of income" and the "allocation of primary income" accounts;

○ The "entrepreneurial income" account;

- The "allocation of other primary income", the "secondary distribution of income" accounts and the "redistribution of income in kind" account;

- The "use of income" (gross, of disposable and of adjusted disposable income) accounts

The second macro-category is represented by the accumulation accounts. Those are flows accounts, recording the various causes of changes in assets and liabilities and related net worth, which includes:

- The capital account, for measuring the acquisitions and disposals of non-financial assets, the variation in net worth and the capital transfer, and includes:

- The "change in net worth due to saving and capital transfers" account;

- The "acquisitions of non-financial assets" account;

- The "financial" account, to record the variations in financial assets;

- The "other changes in assets" and "other changes in volume of assets" accounts and the "revaluation" account, that includes the "neutral holding gains and losses" and "real holding gains and losses" accounts.

A third macro-category is composed by the balance sheets, that includes the opening balance sheet, the variation in balance sheets and the closing balance sheet. This threefold structure is also coherent with the formerly recalled Rational Management Theory.

\section{Sample and Methodology}

The most acknowledged financial statement analysis tools, such as current ratio and equity/asset (also known as financial leverage) ratio, are normally considered as primary gauges of financial health and sustainability. In a government balance sheet, the members of the ratio are not so easy to retrieve, in particular when we come to a standardized accounting framework such as ESA2010. In this contribution, we propose to compare some balance sheet stock to analyze its relation with the Deficit/GDP ratio through a graphical and descriptive comparison.

Our sample is extracted from the European Central Bank's (ECB) statistical data warehouse (ECB-SDW)(“ECB Statistical Data Warehouse" 2016). The ECB-SDW consents the extraction of a pivot Excel worksheet containing the entire database, related to a more or less specific topic, depending on the selected proxies. We retrieve, in particular: 
- Data related to Euro Area Accounts, and in particular the stocks of assets and liabilities, with quarterly frequency, from the "Financial balance sheets and non-financial assets";

- $\quad$ Data related to the Deficit/Surplus, with quarterly and annual frequency.

The extracted databases are generated (and maintained) by the ECB through the implementation of the European Standard of National and Regional Accounts in its 2010 version. In particular, the retrieved data is related to the operator/unit "General Government", including both the Central and the Regional units.

The assets and liabilities, both financial and non-financial, are selected from the Quarterly Sector Accounts (QSA) with the following proxies:

- $\quad$ Frequency: quarterly, reducing the selection to the $2^{\text {nd }}$ and the $4^{\text {th }}$ quarter (i.e., June $30^{\text {th }}$ and December $31^{\text {st }}$ of each year from 2004 to 2015) [on QSA the proxy is called Q];

- $\quad$ Adjustment indicator: the data are adjusted neither seasonally nor on calendar basis [proxy N];

- Counterpart area: we consider the operations with all the World (all units) [proxy W0];

- $\quad$ Reference sector: General Government [proxy S13];

- Counterpart sector: Total economy [proxy S1];

- Consolidation: yes [proxy C];

- Accounting Entries: (net acquisition of) assets [proxy A] and (net incurrence of) liabilities [proxy L];

- $\quad$ Stocks, Transactions, Other Flows: we take under consideration the Closing Balance Sheet positions and stocks [proxy LE];

- Currency denominator and Unit of measure: all currencies [proxy _ T], the unit of measure is the Domestic Currency [proxy XDC];

- Valuation and Prices: the valuation is based on the ESA [proxy S] at current prices [proxy V], without transformation [proxy N];

- Instruments and assets classification: we consider the total Assets and Liabilities [proxy F];

- Countries: we took under considerations all the countries of the European Union (28 countries).

The first sample is composed by 497 entries considering both assets and liabilities, at each date, for each Country. We calculated the ratio between Assets and Liabilities, multiplying it by 100 to obtain a percent value, for each Country under consideration.

The second sample is related to the Deficit/Surplus to Gross Domestic Product ratio, extracted from the ESA Deficit/Surplus database in the Government Finance Statistics section of the ECB-SDW. Applying the same Country and date proxies, the sample results to be composed by 672 entries. This dataset is larger than the former because some Country data for assets and liabilities hasn't been recorded for some of the years we took under consideration.

In order to compare the retrieved data, we merged the samples by date and Country, eliminating those entries that have missing data in one of the two datasets. This operation results in a dataset of 497 entries, sorted by date and Country.

The comparison is both graphical and statistical; by the means of a mono-variate classic linear regression model with the OLS estimator, where the model is

$$
\text { DGDPRATIO }=\beta_{0}+\beta_{1} A S L I
$$

where DGDPRATIO stands for Deficit/GDP Ratio, which is set to be the dependent variable, and ASLI stands for Assets/Liabilities ratio, which is set to be de explanatory variable. The comparison and the regression have been divided by Country.

The dataset, data key and data descriptive statistics can be found in the appendixes.

\section{Comparative Data of EU28}

We propose hereunder the comparative data between the selected variables with both the methodologies. The data are sorted by significance of the coefficient ( $p$-value at least smaller than 0.05 ) and adaptability of the model ( $R$-squared value). (Note 1$)$

The results of the model applied to Netherlands, Belgium, Hungary, Germany and Finland resulted in a statistically significant correlation between the Assets/Liabilities ratio and the Deficit/GDP ratio and a R-squared value greater 
than 0.25 . The correlation is negative in the first three countries and positive in the last two countries.

Table 1. Relevant and significant regression estimates

\begin{tabular}{|c|c|c|c|c|c|c|c|c|}
\hline \multirow{5}{*}{ NL } & \multirow{2}{*}{$\begin{array}{l}y=\text { dgdpratio } \\
A S L I\end{array}$} & \multirow{2}{*}{$\begin{array}{l}\text { Coeff. }(\boldsymbol{\beta}) \\
-0.7385\end{array}$} & \multirow{2}{*}{$\frac{\text { Std.Err. }}{0.2555}$} & \multirow{2}{*}{$\frac{\mathbf{t}}{-2.8900}$} & \multirow{2}{*}{$\frac{\mathbf{P}>\mathbf{t}}{0.0160}$} & \multicolumn{2}{|c|}{ [95\% Conf. Interval] } & \multirow{2}{*}{$\begin{array}{l}\text { Significant? } \\
*\end{array}$} \\
\hline & & & & & & -1.3078 & -0.1691 & \\
\hline & intercept & 37.9365 & 14.2576 & 2.6600 & 0.0240 & 6.1686 & 69.7043 & \\
\hline & $R$-squared & 0.4551 & & & & & & \\
\hline & Root MSE & 1.9765 & & & & & & \\
\hline \multirow{5}{*}{$\mathrm{BE}$} & $y=$ dgdpratio & Coeff. ( $\beta$ ) & Std.Err. & $\mathbf{t}$ & $\mathbf{P}>\mathbf{t}$ & \multicolumn{2}{|c|}{ [95\% Conf. Interval] } & Significant? \\
\hline & $A S L I$ & -0.5663 & 0.1464 & -3.8700 & 0.0010 & -0.8699 & -0.2627 & $* *$ \\
\hline & intercept & 19.5847 & 4.4271 & 4.4200 & 0.0000 & 10.4034 & 28.7661 & \\
\hline & $R$-squared & 0.4048 & & & & & & \\
\hline & Root MSE & 1.9194 & & & & & & \\
\hline \multirow{5}{*}{$\mathrm{HU}$} & $y=d g d p r a t i o$ & Coeff. ( $\beta$ ) & Std.Err. & $\mathbf{t}$ & $\mathbf{P}>\mathbf{t}$ & \multicolumn{2}{|c|}{ [95\% Conf. Interval] } & Significant? \\
\hline & $A S L I$ & -0.3777 & 0.1178 & -3.2100 & 0.0040 & -0.6221 & -0.1334 & $* *$ \\
\hline & intercept & 7.8079 & 3.8287 & 2.0400 & 0.0540 & -0.1322 & 15.7480 & \\
\hline & $R$-squared & 0.3185 & & & & & & \\
\hline & Root MSE & 2.1241 & & & & & & \\
\hline \multirow{5}{*}{$\mathrm{DE}$} & $y=$ dgdpratio & Coeff. ( $\beta$ ) & Std.Err. & $\mathbf{t}$ & $\mathbf{P}>\mathbf{t}$ & \multicolumn{2}{|c|}{ [95\% Conf. Interval] } & Significant? \\
\hline & $A S L I$ & 0.1885 & 0.0651 & 2.8900 & 0.0080 & 0.0534 & 0.3236 & $* *$ \\
\hline & intercept & -7.6901 & 2.5599 & -3.0000 & 0.0070 & -12.9989 & -2.3813 & \\
\hline & $R$-squared & 0.2758 & & & & & & \\
\hline & Root MSE & 1.5108 & & & & & & \\
\hline \multirow{5}{*}{ FI } & $y=$ dgdpratio & Coeff. ( $\beta$ ) & Std.Err. & $\mathbf{t}$ & $P>t$ & \multicolumn{2}{|c|}{ [95\% Conf. Interval] } & Significant? \\
\hline & $A S L I$ & 0.1100 & 0.0402 & 2.7400 & 0.0120 & 0.0267 & 0.1933 & $*$ \\
\hline & intercept & -22.3072 & 8.1774 & -2.7300 & 0.0120 & -39.2662 & -5.3483 & \\
\hline & $R$-squared & 0.2543 & & & & & & \\
\hline & Root MSE & 5.5586 & & & & & & \\
\hline
\end{tabular}
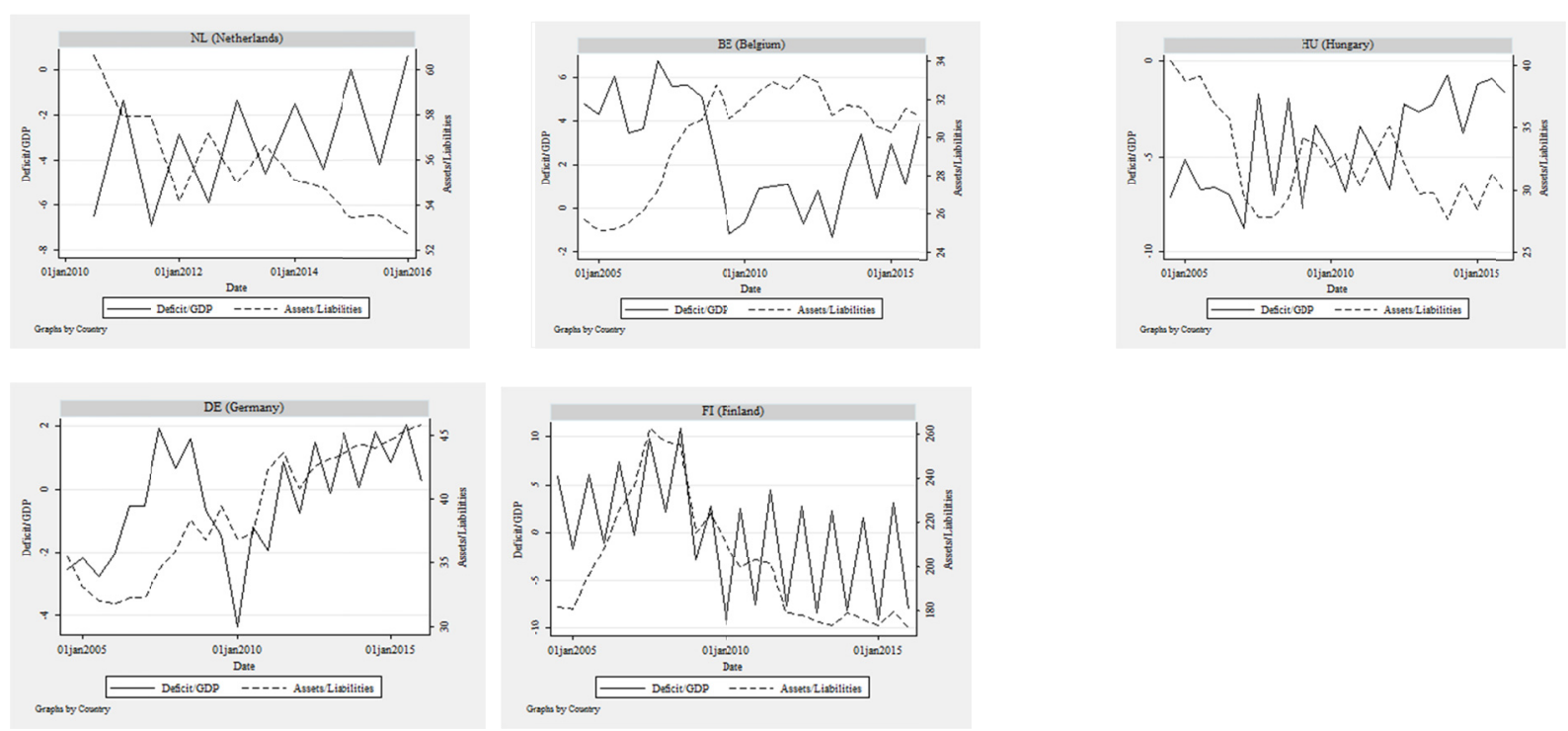

Figures 2. NL $-\mathrm{BE}-\mathrm{HU}-\mathrm{DE}-\mathrm{FI}$ comparative graphs

When coming to Denmark, Croatia, Italy, Ireland and Bulgaria, the R-squared value is still greater than 0.2. At the same time, the $p$-value for the $\beta$ coefficient of Assets/Liabilities ratio is greater than 0.1 , so that the correlation is not statistically significant. The correlation is, in these cases, positive except in the case of Croatia. 
Table 2. Relevant and not significant regression estimates

\begin{tabular}{|c|c|c|c|c|c|c|c|c|}
\hline \multirow{5}{*}{ DK } & \multirow{2}{*}{$\begin{array}{l}\boldsymbol{y}=\text { dgdpratio } \\
A S L I\end{array}$} & \multirow{2}{*}{$\begin{array}{l}\text { Coeff. }(\boldsymbol{\beta}) \\
0.9771\end{array}$} & \multirow{2}{*}{$\begin{array}{l}\text { Std.Err. } \\
0.5513\end{array}$} & \multirow{2}{*}{$\begin{array}{l}\mathbf{t} \\
1.7700\end{array}$} & \multirow{2}{*}{$\frac{\mathbf{P}>\mathbf{t}}{0.1370}$} & \multicolumn{2}{|c|}{ [95\% Conf. Interval] } & \multirow[t]{2}{*}{ Significant? } \\
\hline & & & & & & -0.4402 & 2.3943 & \\
\hline & intercept & -90.8631 & 51.1097 & -1.7800 & 0.1360 & -222.2446 & 40.5185 & \\
\hline & $R$-squared & 0.3858 & & & & & & \\
\hline & Root MSE & 1.6302 & & & & & & \\
\hline \multirow{5}{*}{ HR } & $y=$ dgdpratio & Coeff. $(\beta)$ & Std.Err. & $\mathbf{t}$ & $P>t$ & \multicolumn{2}{|c|}{ [95\% Conf. Interval] } & Significant? \\
\hline & $A S L I$ & -0.4643 & 0.2536 & -1.8300 & 0.1170 & -1.0847 & 0.1561 & \\
\hline & intercept & 25.6909 & 16.9153 & 1.5200 & 0.1800 & -15.6995 & 67.0812 & \\
\hline & $R$-squared & 0.3585 & & & & & & \\
\hline & Root MSE & 1.1369 & & & & & & \\
\hline \multirow{5}{*}{ IT } & $y=$ dgdpratio & Coeff. $(\beta)$ & Std.Err. & t & $\mathbf{P}>\mathbf{t}$ & \multicolumn{2}{|c|}{ [95\% Conf. Interval] } & Significant? \\
\hline & $A S L I$ & 0.3707 & 0.2228 & 1.6600 & 0.1470 & -0.1745 & 0.9160 & \\
\hline & intercept & -9.3684 & 4.6531 & -2.0100 & 0.0910 & -20.7542 & 2.0173 & \\
\hline & $R$-squared & 0.3157 & & & & & & \\
\hline & Root MSE & 0.6279 & & & & & & \\
\hline \multirow{5}{*}{ IE } & $y=$ dgdpratio & Coeff. $(\beta)$ & Std.Err. & $\mathbf{t}$ & $P>t$ & \multicolumn{2}{|c|}{ [95\% Conf. Interval] } & Significant? \\
\hline & $A S L I$ & 2.0328 & 1.3604 & 1.4900 & 0.1860 & -1.2960 & 5.3617 & \\
\hline & intercept & -78.5627 & 49.9109 & -1.5700 & 0.1670 & -200.6902 & 43.5648 & \\
\hline & $R$-squared & 0.2712 & & & & & & \\
\hline & Root MSE & 2.4804 & & & & & & \\
\hline \multirow{5}{*}{ BG } & $y=$ dgdpratio & Coeff. ( $(\beta)$ & Std.Err. & $\mathbf{t}$ & $\mathbf{P}>\mathbf{t}$ & \multicolumn{2}{|c|}{ [95\% Conf. Interval] } & Significant? \\
\hline & $A S L I$ & 0.2761 & 0.2272 & 1.2100 & 0.2790 & -0.3080 & 0.8602 & \\
\hline & intercept & -32.8399 & 23.1435 & -1.4200 & 0.2150 & -92.3321 & 26.6522 & \\
\hline & $R$-squared & 0.2279 & & & & & & \\
\hline & Root MSE & 5.6914 & & & & & & \\
\hline
\end{tabular}
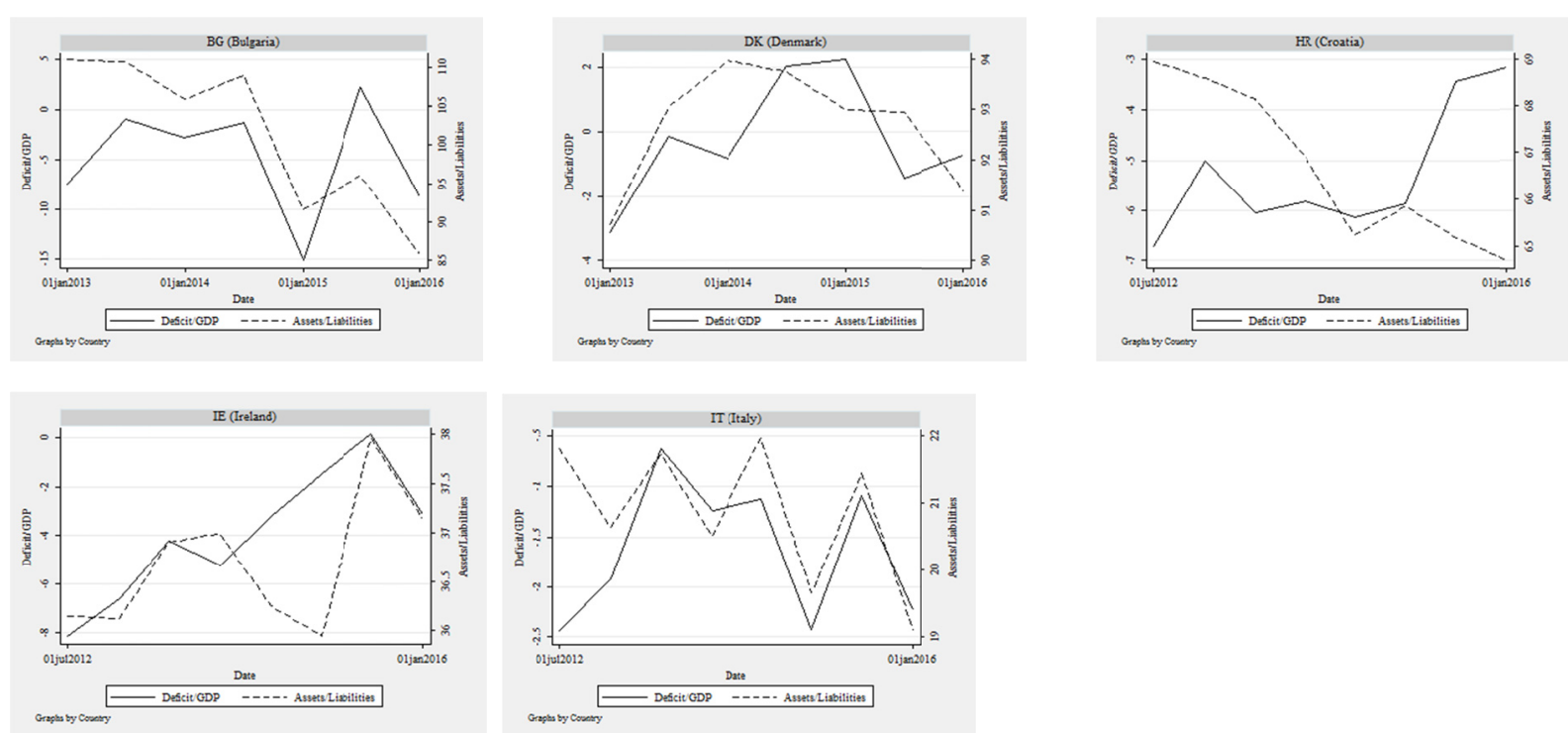

Figures 3 . DK - HR - IE - IT - BG comparative graphs

For the remaining 18 countries, both the R-squared value and the $p$-value of the $\beta_{1}$ coefficient smaller than the aforementioned thresholds, so the model is to be considered not significant in those cases.

The graphs regarding those countries can be found in the appendix.

\section{Conclusion}

At a first glance, from the graphical analysis emerges a way weaker influence from external factors on the Assets/Liabilities rather than on the Deficit/GDP ratio, which presents a highly volatile evolution. 
The double quantitative and graphical analysis shows also how the Assets/Liabilities compositions can in some cases have a correlation with the Deficit/GDP ratio. This correlation tends to be negative in Netherlands, Belgium, Hungary and Croatia, whilst in Germany, Finland, Denmark, Italy, Ireland and Bulgaria it tends to be strictly positive. This could mean that the influence of the investments and funding composition could affect separately the SGP's ratio. In order to enhance the comprehension of these phenomena, further studies must be conducted, focusing on the composition of the numerator and denominator of the Assets/Liabilities ratio, both temporally and by source and nature of each entry. Moreover, more extensive analyses and quantitative researches have to be conducted in order to define some more suitable variables to be considered for public sector financial analysis, management and decision making.

\section{References}

Beetsma, R., \& Harald, U. (1999). An Analysis of the Stability and Growth Pact. The Economic Journal, 109(458), 546-571. https://doi.org/10.1111/1468-0297.00462

Bhushan, N., \& Kanwal, R. (2007). Strategic Decision Making: Applying the Analytic Hierarchy Process. Springer Science \& Business Media.

Buti, M. (2007). Will the New Stability and Growth Pact Succeed? An Economic and Political Perspective.” In The Stability and Growth Pact Experiences and Future Aspects, edited by Univ-Prof Dr Fritz Breuss, 155-81. Schriftenreihe Der Österreichischen Gesellschaft Für Europaforschung (ECSA Austria) / European Community Studies Association of Austria Publication Series 10. Springer Vienna. http://link.springer.com/chapter/10.1007/978-3-211-49307-6_8

Buti, M., Daniele, F., \& Hedwig, O. (1997). Budgetary Policies during Recessions Retrospective Application of the 'Stability and Growth Pact' to the Post-War Period. Recherches Économiques de Louvain / Louvain Economic Review, 63(4), 321-366.

Buti, M., Sylvester, C., Eijffinger, W., \& Daniele, F. (2003). Revisiting the Stability and Growth Pact: Grand Design or Internal Adjustment? SSRN Scholarly Paper ID 374461. Rochester, NY: Social Science Research Network. http://papers.ssrn.com/abstract $=374461$.

ECB Statistical Data Warehouse. (2016). Accessed May 12. http://sdw.ecb.europa.eu/

EUROSTAT. (2016) - ESA 2010 - Overview. Accessed May 12. http://ec.europa.eu/eurostat/web/esa-2010

Haan, de, Jakob, Helge Berger, and David-Jan Jansen. (2003). The End of the Stability and Growth Pact? SSRN Scholarly Paper ID 479461. Rochester, NY: Social Science Research Network. http://papers.ssrn.com/abstract=479461.

Potter, B. H., \& Jack, D. (1999). Guidelines for Public Expenditure Management. International Monetary Fund.

Puddu, L. (2008). Bilancio Ipsas: sistema integrato di rilevazioni e principi contabili pubblici. RIREA.

Schuknecht, L., Philippe, M., Philipp, R., \& Jürgen, S. (2011). The Stability and Growth Pact: Crisis and Reform. SSRN Scholarly Paper ID 1791598. Rochester, NY: Social Science Research Network. Retrieved from http://papers.ssrn.com/abstract=1791598

\section{Appendix}

\section{Appendix A - Data key table}

Table 3. Country key

\begin{tabular}{llll}
\hline AT & Austria & HU & Hungary \\
\hline BE & Belgium & IE & Ireland \\
BG & Bulgaria & IT & Italy \\
CY & Cyprus & LT & Lithuania \\
CZ & Czech Republic & LU & Luxembourg \\
DE & Germany & LV & Latvia \\
DK & Denmark & MT & Malta \\
EE & Estonia & NL & Netherlands \\
ES & Spain & PL & Poland \\
FI & Finland & PT & Portugal \\
FR & France & RO & Romania \\
\hline
\end{tabular}




\begin{tabular}{llll}
\hline GB & United Kingdom & SE & Sweden \\
GR & Greece & SI & Slovenia \\
HR & Croatia & SK & Slovakia \\
\hline
\end{tabular}

\section{Appendix B - Descriptive statistics table}

Table 4. Descriptive statistics

\begin{tabular}{|c|c|c|c|c|c|c|}
\hline Country & Variable & Obs. & Mean & Std. Dev. & Min & Max \\
\hline \multirow{2}{*}{$\mathrm{AT}$} & dgdpratio & 20 & -1.3190 & 1.8430 & -4.9732 & 1.5242 \\
\hline & $A S L I$ & 20 & 51.6313 & 2.1071 & 47.3440 & 55.8248 \\
\hline \multirow{2}{*}{$\mathrm{BE}$} & dgdpratio & 24 & 2.5258 & 2.4333 & -1.3269 & 6.7418 \\
\hline & $A S L I$ & 24 & 30.1249 & 2.7341 & 25.0959 & 33.2646 \\
\hline \multirow{2}{*}{ BG } & dgdpratio & 7 & -4.8440 & 5.9128 & -15.1126 & 2.2196 \\
\hline & $A S L I$ & 7 & 101.4081 & 10.2251 & 85.7285 & 111.0076 \\
\hline \multirow{2}{*}{$\mathrm{CY}$} & dgdpratio & 7 & -5.5917 & 4.7304 & -11.5370 & 0.3819 \\
\hline & $A S L I$ & 7 & 57.2156 & 1.8050 & 55.2018 & 60.0387 \\
\hline \multirow{2}{*}{$\mathrm{CZ}$} & dgdpratio & 16 & -2.8865 & 2.8103 & -9.3638 & 0.7812 \\
\hline & $A S L I$ & 16 & 84.9585 & 24.4071 & 59.8940 & 145.9148 \\
\hline \multirow{2}{*}{$\mathrm{DE}$} & dgdpratio & 24 & -0.3354 & 1.7362 & -4.3818 & 2.0138 \\
\hline & $A S L I$ & 24 & 39.0192 & 4.8371 & 31.8227 & 45.7740 \\
\hline \multirow{2}{*}{ DK } & dgdpratio & 7 & -0.2921 & 1.8989 & -3.1208 & 2.2328 \\
\hline & $A S L I$ & 7 & 92.6953 & 1.2071 & 90.7196 & 93.9850 \\
\hline \multirow{2}{*}{$\mathrm{EE}$} & dgdpratio & 12 & 0.9046 & 1.5579 & -1.0517 & 3.6704 \\
\hline & $A S L I$ & 12 & 328.9517 & 42.9769 & 287.6881 & 420.3725 \\
\hline \multirow{2}{*}{ ES } & dgdpratio & 24 & -8.1182 & 5.7696 & -18.1906 & 1.3166 \\
\hline & $A S L I$ & 24 & 49.3592 & 6.4872 & 40.8253 & 63.1230 \\
\hline \multirow{2}{*}{ FI } & dgdpratio & 24 & -0.1243 & 6.2955 & -9.6005 & 10.8294 \\
\hline & $A S L I$ & 24 & 201.6686 & 28.8629 & 171.9460 & 262.6207 \\
\hline \multirow{2}{*}{ FR } & dgdpratio & 24 & -2.0212 & 1.8916 & -5.8188 & 1.0525 \\
\hline & $A S L I$ & 24 & 50.5351 & 5.6984 & 43.8392 & 63.0064 \\
\hline \multirow{2}{*}{ GB } & dgdpratio & 24 & -7.6502 & 2.8881 & -13.3334 & -3.9553 \\
\hline & $A S L I$ & 24 & 38.8694 & 4.2564 & 31.1362 & 43.8816 \\
\hline \multirow{2}{*}{ GR } & dgdpratio & 7 & -8.9192 & 10.2200 & -30.0807 & -2.1997 \\
\hline & $A S L I$ & 7 & 32.8413 & 6.5661 & 24.4493 & 41.1142 \\
\hline \multirow{2}{*}{ HR } & dgdpratio & 8 & -5.2747 & 1.3142 & -6.7209 & -3.1471 \\
\hline & $A S L I$ & 8 & 66.6945 & 1.6948 & 64.6895 & 68.9592 \\
\hline \multirow{2}{*}{$\mathrm{HU}$} & dgdpratio & 24 & -4.3888 & 2.5164 & -8.7928 & -0.7476 \\
\hline & $A S L I$ & 24 & 32.2891 & 3.7595 & 27.5744 & 40.3356 \\
\hline \multirow{2}{*}{ IE } & dgdpratio & 8 & -3.9952 & 2.6900 & -8.1628 & 0.1280 \\
\hline & $A S L I$ & 8 & 36.6817 & 0.6891 & 35.9406 & 37.9596 \\
\hline \multirow{2}{*}{ IT } & dgdpratio & 8 & -1.6357 & 0.7027 & -2.4375 & -0.6198 \\
\hline & $A S L I$ & 8 & 20.8585 & 1.0651 & 19.0963 & 21.9666 \\
\hline \multirow{2}{*}{$\mathrm{LT}$} & dgdpratio & 24 & -4.4777 & 5.3249 & -22.4122 & 2.9562 \\
\hline & $A S L I$ & 24 & 98.8040 & 38.6802 & 56.0930 & 160.2165 \\
\hline \multirow{2}{*}{ LU } & dgdpratio & 24 & 1.9338 & 2.7384 & -3.3904 & 6.6301 \\
\hline & $A S L I$ & 24 & 353.9913 & 107.7086 & 240.3856 & 531.1871 \\
\hline \multirow{2}{*}{ LV } & dgdpratio & 24 & -5.1003 & 6.6096 & -17.0820 & 3.3460 \\
\hline & $A S L I$ & 24 & 96.6562 & 26.8940 & 62.7812 & 140.5902 \\
\hline \multirow{2}{*}{ MT } & dgdpratio & 24 & -2.0621 & 3.1948 & -9.3529 & 4.2108 \\
\hline & $A S L I$ & 24 & 39.8568 & 2.5184 & 35.0024 & 45.2743 \\
\hline NI & dgdpratio & 12 & -3.2335 & 2.5529 & -6.9527 & 0.6571 \\
\hline $\mathrm{NL}$ & $A S L I$ & 12 & 55.7504 & 2.3321 & 52.7040 & 60.6172 \\
\hline DI & dgdpratio & 24 & -6.0168 & 2.6958 & -12.8871 & -2.6992 \\
\hline PL & $A S L I$ & 24 & 58.9628 & 8.0648 & 47.2208 & 73.4945 \\
\hline PT & dgdpratio & 24 & -6.7301 & 4.2391 & -18.4889 & -0.6234 \\
\hline $\mathrm{PT}$ & ASLI & 24 & 39.1144 & 3.1552 & 33.9515 & 47.1394 \\
\hline
\end{tabular}




\begin{tabular}{lllllll}
\hline Country & Variable & Obs. & Mean & Std. Dev. & Min & Max \\
\hline \multirow{2}{*}{ RO } & dgdpratio & 18 & -5.2829 & 4.0237 & -11.4360 & 1.6719 \\
& ASLI & 18 & 93.1522 & 37.1445 & 61.2658 & 174.4914 \\
SE & dgdpratio & 24 & 0.3521 & 3.5492 & -4.7283 & 6.6415 \\
& ASLI & 24 & 122.3980 & 15.2392 & 88.8404 & 142.8542 \\
SI & dgdpratio & 24 & -4.9096 & 7.9813 & -40.4032 & 1.1291 \\
& ASLI & 24 & 105.7867 & 18.9104 & 82.0888 & 141.4996 \\
SK & dgdpratio & 7 & -3.8062 & 1.9239 & -6.8656 & -1.5418 \\
& ASLI & 7 & 60.3726 & 1.8429 & 57.9057 & 63.1434 \\
\hline
\end{tabular}

\section{Appendix C - Dataset}

Table 4. Dataset

\begin{tabular}{|c|c|c|c|}
\hline Country & Date & $\begin{array}{l}\text { DEFICIT } \\
/ \text { GDP } \%\end{array}$ & AS/LI \% \\
\hline AT & $30 / 06 / 2006$ & -1.5309 & 55.2774 \\
\hline AT & $31 / 12 / 2006$ & -0.1724 & 51.9799 \\
\hline AT & $30 / 06 / 2007$ & -0.3009 & 55.8248 \\
\hline AT & $31 / 12 / 2007$ & 1.4130 & 53.5285 \\
\hline AT & $30 / 06 / 2008$ & -0.6288 & 53.6962 \\
\hline AT & $31 / 12 / 2008$ & -0.1425 & 51.0806 \\
\hline AT & $30 / 06 / 2009$ & -3.5643 & 52.3863 \\
\hline AT & $31 / 12 / 2009$ & -4.9732 & 49.5252 \\
\hline AT & $30 / 06 / 2010$ & -2.8798 & 47.3440 \\
\hline AT & $31 / 12 / 2010$ & -1.1341 & 50.2128 \\
\hline AT & $30 / 06 / 2011$ & -1.5497 & 49.4567 \\
\hline AT & $31 / 12 / 2011$ & -2.1520 & 49.1955 \\
\hline AT & $30 / 06 / 2012$ & -3.1638 & 51.1124 \\
\hline $\mathbf{A T}$ & $31 / 12 / 2012$ & 0.3792 & 51.2992 \\
\hline AT & $30 / 06 / 2013$ & -1.8131 & 51.0021 \\
\hline AT & $31 / 12 / 2013$ & 1.5242 & 50.8350 \\
\hline AT & $30 / 06 / 2014$ & -0.4061 & 50.7820 \\
\hline AT & $31 / 12 / 2014$ & -4.9211 & 51.2513 \\
\hline AT & $30 / 06 / 2015$ & -0.4925 & 53.9019 \\
\hline AT & $31 / 12 / 2015$ & 0.1295 & 52.9351 \\
\hline BE & $30 / 06 / 2004$ & 4.7587 & 25.6626 \\
\hline BE & $31 / 12 / 2004$ & 4.3256 & 25.0959 \\
\hline BE & $30 / 06 / 2005$ & 6.0291 & 25.1572 \\
\hline BE & $31 / 12 / 2005$ & 3.4445 & 25.4867 \\
\hline BE & $30 / 06 / 2006$ & 3.6572 & 26.1477 \\
\hline BE & $31 / 12 / 2006$ & 6.7418 & 27.1897 \\
\hline BE & $30 / 06 / 2007$ & 5.5879 & 29.4194 \\
\hline $\mathbf{B E}$ & $31 / 12 / 2007$ & 5.6410 & 30.6014 \\
\hline BE & $30 / 06 / 2008$ & 5.0958 & 30.9530 \\
\hline BE & $31 / 12 / 2008$ & 2.1633 & 32.7620 \\
\hline $\mathbf{B E}$ & $30 / 06 / 2009$ & -1.1689 & 30.9825 \\
\hline BE & $31 / 12 / 2009$ & -0.6768 & 31.6413 \\
\hline BE & $30 / 06 / 2010$ & 0.8756 & 32.3919 \\
\hline BE & $31 / 12 / 2010$ & 0.9801 & 32.9216 \\
\hline $\mathbf{B E}$ & $30 / 06 / 2011$ & 1.0661 & 32.4657 \\
\hline BE & $31 / 12 / 2011$ & -0.7338 & 33.2646 \\
\hline BE & $30 / 06 / 2012$ & 0.7909 & 32.8826 \\
\hline BE & $31 / 12 / 2012$ & -1.3269 & 31.1675 \\
\hline BE & $30 / 06 / 2013$ & 1.5963 & 31.6698 \\
\hline BE & $31 / 12 / 2013$ & 3.4223 & 31.5863 \\
\hline BE & $30 / 06 / 2014$ & 0.4081 & 30.6214 \\
\hline
\end{tabular}




\begin{tabular}{|c|c|c|c|}
\hline Country & Date & $\begin{array}{l}\text { DEFICIT } \\
\text { / GDP \% } \\
\end{array}$ & AS/LI \% \\
\hline BE & $31 / 12 / 2014$ & 2.9601 & 30.2954 \\
\hline BE & $30 / 06 / 2015$ & 1.0756 & 31.5189 \\
\hline BE & $31 / 12 / 2015$ & 3.9043 & 31.1128 \\
\hline BG & $31 / 12 / 2012$ & -7.3900 & 111.0076 \\
\hline BG & $30 / 06 / 2013$ & -0.9095 & 110.6800 \\
\hline BG & $31 / 12 / 2013$ & -2.7466 & 105.8503 \\
\hline BG & $30 / 06 / 2014$ & -1.2406 & 108.9946 \\
\hline BG & $31 / 12 / 2014$ & -15.1126 & 91.5361 \\
\hline BG & $30 / 06 / 2015$ & 2.2196 & 96.0596 \\
\hline BG & $31 / 12 / 2015$ & -8.7280 & 85.7285 \\
\hline CY & $31 / 12 / 2012$ & -11.2524 & 60.0387 \\
\hline CY & $30 / 06 / 2013$ & -4.1323 & 58.3886 \\
\hline CY & $31 / 12 / 2013$ & -11.5370 & 57.7953 \\
\hline CY & $30 / 06 / 2014$ & 0.3819 & 57.9073 \\
\hline CY & $31 / 12 / 2014$ & -5.8863 & 55.4511 \\
\hline CY & $30 / 06 / 2015$ & -0.2767 & 55.7262 \\
\hline CY & $31 / 12 / 2015$ & -6.4395 & 55.2018 \\
\hline $\mathbf{C Z}$ & $30 / 06 / 2008$ & -0.6566 & 145.9148 \\
\hline $\mathrm{CZ}$ & $31 / 12 / 2008$ & -5.5659 & 116.0474 \\
\hline $\mathbf{C Z}$ & $30 / 06 / 2009$ & -3.1016 & 113.8862 \\
\hline $\mathrm{CZ}$ & $31 / 12 / 2009$ & -7.0407 & 102.7690 \\
\hline $\mathbf{C Z}$ & $30 / 06 / 2010$ & -2.0716 & 95.2136 \\
\hline $\mathbf{C Z}$ & $31 / 12 / 2010$ & -5.6564 & 89.6805 \\
\hline $\mathrm{CZ}$ & $30 / 06 / 2011$ & -1.0829 & 82.2926 \\
\hline $\mathbf{C Z}$ & $31 / 12 / 2011$ & -4.2036 & 81.1550 \\
\hline $\mathbf{C Z}$ & $30 / 06 / 2012$ & -0.9919 & 77.8599 \\
\hline $\mathrm{CZ}$ & $31 / 12 / 2012$ & -9.3638 & 71.2108 \\
\hline $\mathrm{CZ}$ & $30 / 06 / 2013$ & -0.8055 & 66.1559 \\
\hline $\mathrm{CZ}$ & $31 / 12 / 2013$ & -0.7238 & 68.2818 \\
\hline $\mathrm{CZ}$ & $30 / 06 / 2014$ & -0.6087 & 63.8038 \\
\hline $\mathrm{CZ}$ & $31 / 12 / 2014$ & -3.6091 & 59.8940 \\
\hline $\mathrm{CZ}$ & $30 / 06 / 2015$ & 0.7812 & 63.6896 \\
\hline $\mathbf{C Z}$ & $31 / 12 / 2015$ & -1.4835 & 61.4805 \\
\hline DE & $30 / 06 / 2004$ & -2.5593 & 35.4719 \\
\hline DE & $31 / 12 / 2004$ & -2.2080 & 33.0800 \\
\hline DE & $30 / 06 / 2005$ & -2.7869 & 32.0507 \\
\hline DE & $31 / 12 / 2005$ & -2.0726 & 31.8227 \\
\hline DE & $30 / 06 / 2006$ & -0.5151 & 32.2439 \\
\hline DE & $31 / 12 / 2006$ & -0.5286 & 32.2593 \\
\hline DE & $30 / 06 / 2007$ & 1.8927 & 34.5027 \\
\hline DE & $31 / 12 / 2007$ & 0.6691 & 35.9372 \\
\hline DE & $30 / 06 / 2008$ & 1.5586 & 38.4614 \\
\hline DE & $31 / 12 / 2008$ & -0.6736 & 36.8035 \\
\hline DE & $30 / 06 / 2009$ & -1.4441 & 39.4838 \\
\hline DE & $31 / 12 / 2009$ & -4.3818 & 36.9238 \\
\hline DE & $30 / 06 / 2010$ & -1.1971 & 37.2958 \\
\hline DE & $31 / 12 / 2010$ & -1.9336 & 42.3169 \\
\hline DE & $30 / 06 / 2011$ & 0.8398 & 43.5761 \\
\hline DE & $31 / 12 / 2011$ & -0.7613 & 40.8775 \\
\hline DE & $30 / 06 / 2012$ & 1.4511 & 42.5767 \\
\hline DE & $31 / 12 / 2012$ & -0.1441 & 43.0991 \\
\hline DE & $30 / 06 / 2013$ & 1.7776 & 43.5750 \\
\hline DE & $31 / 12 / 2013$ & 0.0743 & 44.2868 \\
\hline DE & $30 / 06 / 2014$ & 1.7980 & 44.0075 \\
\hline
\end{tabular}




\begin{tabular}{|c|c|c|c|}
\hline Country & Date & $\begin{array}{l}\text { DEFICIT } \\
\text { / GDP \% }\end{array}$ & AS/LI \% \\
\hline DE & $31 / 12 / 2014$ & 0.8415 & 44.6465 \\
\hline DE & $30 / 06 / 2015$ & 2.0138 & 45.3877 \\
\hline DE & $31 / 12 / 2015$ & 0.2409 & 45.7740 \\
\hline DK & $31 / 12 / 2012$ & -3.1208 & 90.7196 \\
\hline DK & $30 / 06 / 2013$ & -0.1528 & 93.0655 \\
\hline DK & $31 / 12 / 2013$ & -0.8093 & 93.9850 \\
\hline DK & $30 / 06 / 2014$ & 2.0300 & 93.7538 \\
\hline DK & $31 / 12 / 2014$ & 2.2328 & 93.0082 \\
\hline DK & $30 / 06 / 2015$ & -1.4544 & 92.9626 \\
\hline DK & $31 / 12 / 2015$ & -0.7701 & 91.3725 \\
\hline $\mathbf{E E}$ & $30 / 06 / 2010$ & -1.0003 & 296.1333 \\
\hline $\mathbf{E E}$ & $31 / 12 / 2010$ & 1.4148 & 371.2596 \\
\hline EE & $30 / 06 / 2011$ & 3.6704 & 374.0393 \\
\hline EE & $31 / 12 / 2011$ & -1.0517 & 420.3725 \\
\hline $\mathbf{E E}$ & $30 / 06 / 2012$ & 1.7207 & 367.0345 \\
\hline $\mathbf{E E}$ & $31 / 12 / 2012$ & -1.0065 & 319.6952 \\
\hline $\mathbf{E E}$ & $30 / 06 / 2013$ & 1.4851 & 308.1052 \\
\hline $\mathbf{E E}$ & $31 / 12 / 2013$ & -0.9844 & 310.0947 \\
\hline $\mathbf{E E}$ & $30 / 06 / 2014$ & 1.2348 & 287.6881 \\
\hline $\mathbf{E E}$ & $31 / 12 / 2014$ & 2.4380 & 303.2009 \\
\hline $\mathbf{E E}$ & $30 / 06 / 2015$ & 1.5526 & 289.9831 \\
\hline $\mathbf{E E}$ & $31 / 12 / 2015$ & 1.3818 & 299.8142 \\
\hline ES & $30 / 06 / 2004$ & -3.5563 & 41.1101 \\
\hline ES & $31 / 12 / 2004$ & -0.9667 & 42.4681 \\
\hline ES & $30 / 06 / 2005$ & -2.2880 & 44.2958 \\
\hline ES & $31 / 12 / 2005$ & 0.9342 & 48.8651 \\
\hline ES & $30 / 06 / 2006$ & -1.2133 & 51.9754 \\
\hline ES & $31 / 12 / 2006$ & 1.3166 & 56.6207 \\
\hline ES & $30 / 06 / 2007$ & -1.8182 & 59.7006 \\
\hline ES & $31 / 12 / 2007$ & -0.8382 & 63.1230 \\
\hline ES & $30 / 06 / 2008$ & -7.3443 & 60.4721 \\
\hline ES & $31 / 12 / 2008$ & -9.5233 & 58.2634 \\
\hline ES & $30 / 06 / 2009$ & -15.8952 & 54.9789 \\
\hline ES & $31 / 12 / 2009$ & -13.6362 & 51.3814 \\
\hline ES & $30 / 06 / 2010$ & -12.9253 & 49.8650 \\
\hline ES & $31 / 12 / 2010$ & -12.1725 & 48.1154 \\
\hline ES & $30 / 06 / 2011$ & -12.3588 & 48.5725 \\
\hline ES & $31 / 12 / 2011$ & -14.4124 & 46.2304 \\
\hline ES & $30 / 06 / 2012$ & -13.7528 & 47.4440 \\
\hline ES & $31 / 12 / 2012$ & -18.1906 & 48.1024 \\
\hline ES & $30 / 06 / 2013$ & -12.1782 & 47.3802 \\
\hline ES & $31 / 12 / 2013$ & -8.3667 & 45.5174 \\
\hline ES & $30 / 06 / 2014$ & -10.8504 & 45.0212 \\
\hline ES & $31 / 12 / 2014$ & -8.5947 & 42.5087 \\
\hline ES & $30 / 06 / 2015$ & -8.4781 & 41.7845 \\
\hline ES & $31 / 12 / 2015$ & -7.7281 & 40.8253 \\
\hline FI & $30 / 06 / 2004$ & 5.8721 & 181.2389 \\
\hline FI & $31 / 12 / 2004$ & -1.6685 & 180.6135 \\
\hline FI & $30 / 06 / 2005$ & 6.0841 & 195.7860 \\
\hline FI & $31 / 12 / 2005$ & -1.0926 & 208.0377 \\
\hline FI & $30 / 06 / 2006$ & 7.3163 & 225.3914 \\
\hline FI & $31 / 12 / 2006$ & -0.2174 & 237.1742 \\
\hline FI & $30 / 06 / 2007$ & 9.7592 & 262.6207 \\
\hline FI & $31 / 12 / 2007$ & 2.2152 & 256.4996 \\
\hline
\end{tabular}




\begin{tabular}{|c|c|c|c|}
\hline Country & Date & $\begin{array}{l}\text { DEFICIT } \\
\text { / GDP \% }\end{array}$ & AS/LI \% \\
\hline FI & $30 / 06 / 2008$ & 10.8294 & 255.3548 \\
\hline FI & $31 / 12 / 2008$ & -2.9221 & 215.3396 \\
\hline FI & $30 / 06 / 2009$ & 2.8084 & 224.2974 \\
\hline FI & $31 / 12 / 2009$ & -9.6005 & 210.5156 \\
\hline FI & $30 / 06 / 2010$ & 2.5397 & 199.7337 \\
\hline FI & $31 / 12 / 2010$ & -7.5838 & 202.6818 \\
\hline FI & $30 / 06 / 2011$ & 4.4571 & 201.2072 \\
\hline FI & $31 / 12 / 2011$ & -7.7532 & 178.7882 \\
\hline FI & $30 / 06 / 2012$ & 2.7324 & 177.8009 \\
\hline FI & $31 / 12 / 2012$ & -8.4733 & 174.7579 \\
\hline FI & $30 / 06 / 2013$ & 2.3288 & 173.1650 \\
\hline FI & $31 / 12 / 2013$ & -8.1290 & 178.8415 \\
\hline FI & $30 / 06 / 2014$ & 1.6248 & 175.8756 \\
\hline FI & $31 / 12 / 2014$ & -9.1753 & 173.2441 \\
\hline FI & $30 / 06 / 2015$ & 3.1517 & 179.1357 \\
\hline FI & $31 / 12 / 2015$ & -8.0874 & 171.9460 \\
\hline FR & $30 / 06 / 2004$ & -2.3390 & 51.4812 \\
\hline FR & $31 / 12 / 2004$ & 0.2019 & 50.9380 \\
\hline FR & $30 / 06 / 2005$ & -2.2013 & 51.8987 \\
\hline FR & $31 / 12 / 2005$ & 0.0838 & 54.3060 \\
\hline FR & $30 / 06 / 2006$ & -1.3076 & 55.6353 \\
\hline FR & $31 / 12 / 2006$ & 1.0525 & 58.4379 \\
\hline FR & $30 / 06 / 2007$ & -0.0959 & 63.0064 \\
\hline FR & $31 / 12 / 2007$ & -0.2147 & 61.8547 \\
\hline FR & $30 / 06 / 2008$ & -0.4376 & 58.4084 \\
\hline FR & $31 / 12 / 2008$ & -2.2802 & 53.1913 \\
\hline FR & $30 / 06 / 2009$ & -5.8188 & 51.1797 \\
\hline FR & $31 / 12 / 2009$ & -3.9062 & 50.4829 \\
\hline FR & $30 / 06 / 2010$ & -5.2538 & 48.3877 \\
\hline FR & $31 / 12 / 2010$ & -4.1370 & 49.4284 \\
\hline FR & $30 / 06 / 2011$ & -4.2268 & 48.9422 \\
\hline FR & $31 / 12 / 2011$ & -2.2377 & 45.4829 \\
\hline FR & $30 / 06 / 2012$ & -4.3041 & 45.7034 \\
\hline FR & $31 / 12 / 2012$ & -1.3829 & 44.2983 \\
\hline FR & $30 / 06 / 2013$ & -2.6327 & 44.7593 \\
\hline FR & $31 / 12 / 2013$ & -0.9986 & 46.3468 \\
\hline FR & $30 / 06 / 2014$ & -2.6104 & 46.2294 \\
\hline FR & $31 / 12 / 2014$ & -0.8224 & 44.2000 \\
\hline FR & $30 / 06 / 2015$ & -3.0022 & 44.4052 \\
\hline FR & $31 / 12 / 2015$ & 0.3638 & 43.8392 \\
\hline GB & $30 / 06 / 2004$ & -5.6079 & 43.5960 \\
\hline GB & $31 / 12 / 2004$ & -4.9354 & 42.1649 \\
\hline GB & $30 / 06 / 2005$ & -3.9553 & 43.8816 \\
\hline GB & $31 / 12 / 2005$ & -5.9890 & 42.7543 \\
\hline GB & $30 / 06 / 2006$ & -5.3562 & 43.8118 \\
\hline GB & $31 / 12 / 2006$ & -4.1804 & 41.6958 \\
\hline GB & $30 / 06 / 2007$ & -4.6985 & 43.0194 \\
\hline GB & $31 / 12 / 2007$ & -4.7458 & 41.1985 \\
\hline GB & $30 / 06 / 2008$ & -6.2305 & 40.9297 \\
\hline GB & $31 / 12 / 2008$ & -9.2551 & 41.8092 \\
\hline GB & $30 / 06 / 2009$ & -12.8990 & 40.9051 \\
\hline GB & $31 / 12 / 2009$ & -13.3334 & 39.2869 \\
\hline GB & $30 / 06 / 2010$ & -10.5578 & 41.6399 \\
\hline GB & $31 / 12 / 2010$ & -11.8502 & 41.3150 \\
\hline
\end{tabular}




\begin{tabular}{|c|c|c|c|}
\hline Country & Date & $\begin{array}{l}\text { DEFICIT } \\
\text { / GDP \% }\end{array}$ & AS/LI \% \\
\hline GB & $30 / 06 / 2011$ & -9.5558 & 40.4278 \\
\hline GB & $31 / 12 / 2011$ & -9.3846 & 34.6589 \\
\hline GB & $30 / 06 / 2012$ & -11.6582 & 35.1862 \\
\hline GB & $31 / 12 / 2012$ & -9.6931 & 35.5991 \\
\hline GB & $30 / 06 / 2013$ & -5.7345 & 35.4443 \\
\hline GB & $31 / 12 / 2013$ & -8.6041 & 34.7702 \\
\hline GB & $30 / 06 / 2014$ & -6.8109 & 34.1626 \\
\hline GB & $31 / 12 / 2014$ & -6.6620 & 31.1602 \\
\hline GB & $30 / 06 / 2015$ & -5.8672 & 32.3108 \\
\hline GB & $31 / 12 / 2015$ & -6.0399 & 31.1362 \\
\hline GR & $31 / 12 / 2012$ & -6.3895 & 41.1142 \\
\hline GR & $30 / 06 / 2013$ & -30.0807 & 38.9774 \\
\hline GR & $31 / 12 / 2013$ & -2.1997 & 37.1498 \\
\hline GR & $30 / 06 / 2014$ & -2.4642 & 32.6175 \\
\hline GR & $31 / 12 / 2014$ & -3.0250 & 30.2938 \\
\hline GR & $30 / 06 / 2015$ & -4.0961 & 24.4493 \\
\hline GR & $31 / 12 / 2015$ & -14.1789 & 25.2874 \\
\hline HR & $30 / 06 / 2012$ & -6.7209 & 68.9592 \\
\hline HR & $31 / 12 / 2012$ & -5.0121 & 68.6014 \\
\hline HR & $30 / 06 / 2013$ & -6.0571 & 68.1443 \\
\hline HR & $31 / 12 / 2013$ & -5.8224 & 66.9070 \\
\hline HR & $30 / 06 / 2014$ & -6.1427 & 65.2312 \\
\hline HR & $31 / 12 / 2014$ & -5.8624 & 65.8537 \\
\hline HR & $30 / 06 / 2015$ & -3.4331 & 65.1696 \\
\hline HR & $31 / 12 / 2015$ & -3.1471 & 64.6895 \\
\hline $\mathrm{HU}$ & $30 / 06 / 2004$ & -7.1506 & 40.3356 \\
\hline HU & $31 / 12 / 2004$ & -5.1582 & 38.7164 \\
\hline $\mathrm{HU}$ & $30 / 06 / 2005$ & -6.7356 & 39.1363 \\
\hline HU & $31 / 12 / 2005$ & -6.6636 & 36.8950 \\
\hline HU & $30 / 06 / 2006$ & -7.0606 & 35.7021 \\
\hline HU & $31 / 12 / 2006$ & -8.7928 & 29.2301 \\
\hline $\mathrm{HU}$ & $30 / 06 / 2007$ & -1.7295 & 27.7689 \\
\hline HU & $31 / 12 / 2007$ & -7.0204 & 27.7319 \\
\hline $\mathrm{HU}$ & $30 / 06 / 2008$ & -1.9773 & 29.2467 \\
\hline HU & $31 / 12 / 2008$ & -7.7129 & 34.2082 \\
\hline $\mathrm{HU}$ & $30 / 06 / 2009$ & -3.3461 & 33.6866 \\
\hline HU & $31 / 12 / 2009$ & -4.7542 & 31.8686 \\
\hline HU & $30 / 06 / 2010$ & -6.8958 & 32.8618 \\
\hline HU & $31 / 12 / 2010$ & -3.3779 & 30.3574 \\
\hline $\mathrm{HU}$ & $30 / 06 / 2011$ & -4.7145 & 32.9139 \\
\hline HU & $31 / 12 / 2011$ & -6.7547 & 35.1058 \\
\hline $\mathrm{HU}$ & $30 / 06 / 2012$ & -2.2646 & 32.2113 \\
\hline $\mathrm{HU}$ & $31 / 12 / 2012$ & -2.6612 & 29.6392 \\
\hline HU & $30 / 06 / 2013$ & -2.2414 & 29.7059 \\
\hline HU & $31 / 12 / 2013$ & -0.7476 & 27.5744 \\
\hline $\mathrm{HU}$ & $30 / 06 / 2014$ & -3.7349 & 30.5465 \\
\hline $\mathrm{HU}$ & $31 / 12 / 2014$ & -1.2283 & 28.4036 \\
\hline HU & $30 / 06 / 2015$ & -0.9146 & 31.2983 \\
\hline $\mathrm{HU}$ & $31 / 12 / 2015$ & -1.6932 & 29.7942 \\
\hline IE & $30 / 06 / 2012$ & -8.1628 & 36.1480 \\
\hline IE & $31 / 12 / 2012$ & -6.6438 & 36.1185 \\
\hline IE & $30 / 06 / 2013$ & -4.2516 & 36.9028 \\
\hline IE & $31 / 12 / 2013$ & -5.2328 & 36.9938 \\
\hline IE & $30 / 06 / 2014$ & -3.1986 & 36.2517 \\
\hline
\end{tabular}




\begin{tabular}{|c|c|c|c|}
\hline Country & Date & $\begin{array}{l}\text { DEFICIT } \\
\text { / GDP \% }\end{array}$ & AS/LI \% \\
\hline IE & $31 / 12 / 2014$ & -1.4981 & 35.9406 \\
\hline IE & $30 / 06 / 2015$ & 0.1280 & 37.9596 \\
\hline IE & $31 / 12 / 2015$ & -3.1015 & 37.1386 \\
\hline IT & $30 / 06 / 2012$ & -2.4375 & 21.8042 \\
\hline IT & $31 / 12 / 2012$ & -1.9177 & 20.6493 \\
\hline IT & $30 / 06 / 2013$ & -0.6198 & 21.7309 \\
\hline IT & $31 / 12 / 2013$ & -1.2399 & 20.5153 \\
\hline IT & $30 / 06 / 2014$ & -1.1183 & 21.9666 \\
\hline IT & $31 / 12 / 2014$ & -2.4311 & 19.6574 \\
\hline IT & $30 / 06 / 2015$ & -1.0931 & 21.4483 \\
\hline IT & $31 / 12 / 2015$ & -2.2280 & 19.0963 \\
\hline LT & $30 / 06 / 2004$ & -2.8422 & 127.4852 \\
\hline LT & $31 / 12 / 2004$ & -2.8169 & 127.4771 \\
\hline LT & $30 / 06 / 2005$ & 0.5069 & 132.9780 \\
\hline LT & $31 / 12 / 2005$ & -3.7009 & 131.7311 \\
\hline LT & $30 / 06 / 2006$ & 2.9562 & 142.5315 \\
\hline LT & $31 / 12 / 2006$ & -5.6128 & 147.4198 \\
\hline LT & $30 / 06 / 2007$ & -0.8570 & 160.2165 \\
\hline LT & $31 / 12 / 2007$ & -4.5837 & 150.5032 \\
\hline LT & $30 / 06 / 2008$ & -2.1825 & 147.9764 \\
\hline LT & $31 / 12 / 2008$ & -8.5079 & 134.5443 \\
\hline LT & $30 / 06 / 2009$ & -10.3869 & 115.2667 \\
\hline LT & $31 / 12 / 2009$ & -12.3217 & 92.6398 \\
\hline LT & $30 / 06 / 2010$ & -7.5911 & 81.0570 \\
\hline LT & $31 / 12 / 2010$ & -8.8013 & 76.1044 \\
\hline LT & $30 / 06 / 2011$ & -4.8723 & 70.3263 \\
\hline LT & $31 / 12 / 2011$ & -22.4122 & 61.9212 \\
\hline LT & $30 / 06 / 2012$ & -2.1687 & 57.8999 \\
\hline LT & $31 / 12 / 2012$ & -4.3399 & 57.0317 \\
\hline LT & $30 / 06 / 2013$ & -1.3942 & 56.0930 \\
\hline LT & $31 / 12 / 2013$ & -1.2409 & 56.5194 \\
\hline LT & $30 / 06 / 2014$ & -2.5986 & 58.9046 \\
\hline LT & $31 / 12 / 2014$ & -1.1344 & 60.1980 \\
\hline LT & $30 / 06 / 2015$ & 1.7404 & 61.2796 \\
\hline LT & $31 / 12 / 2015$ & -2.3020 & 63.1906 \\
\hline $\mathbf{L U}$ & $30 / 06 / 2004$ & 0.2632 & 461.2274 \\
\hline $\mathbf{L U}$ & $31 / 12 / 2004$ & -3.2656 & 430.9876 \\
\hline $\mathbf{L U}$ & $30 / 06 / 2005$ & 1.7718 & 453.3892 \\
\hline $\mathbf{L U}$ & $31 / 12 / 2005$ & 0.3989 & 458.6943 \\
\hline $\mathbf{L U}$ & $30 / 06 / 2006$ & 6.2395 & 473.4933 \\
\hline $\mathbf{L U}$ & $31 / 12 / 2006$ & -0.5228 & 479.9080 \\
\hline $\mathbf{L U}$ & $30 / 06 / 2007$ & 6.1468 & 498.1925 \\
\hline $\mathbf{L U}$ & $31 / 12 / 2007$ & 4.3246 & 531.1871 \\
\hline $\mathbf{L U}$ & $30 / 06 / 2008$ & 6.6301 & 522.4964 \\
\hline $\mathbf{L U}$ & $31 / 12 / 2008$ & 3.9088 & 362.1335 \\
\hline $\mathbf{L U}$ & $30 / 06 / 2009$ & 2.3898 & 357.6893 \\
\hline $\mathbf{L U}$ & $31 / 12 / 2009$ & -3.3904 & 383.1946 \\
\hline $\mathbf{L U}$ & $30 / 06 / 2010$ & 2.1934 & 294.3668 \\
\hline $\mathbf{L U}$ & $31 / 12 / 2010$ & -1.3190 & 286.8486 \\
\hline $\mathbf{L U}$ & $30 / 06 / 2011$ & 4.0354 & 278.3000 \\
\hline $\mathbf{L U}$ & $31 / 12 / 2011$ & 0.0168 & 257.7731 \\
\hline $\mathbf{L U}$ & $30 / 06 / 2012$ & 2.0026 & 245.0709 \\
\hline $\mathbf{L U}$ & $31 / 12 / 2012$ & -0.5001 & 248.9373 \\
\hline $\mathbf{L U}$ & $30 / 06 / 2013$ & 3.3457 & 242.6151 \\
\hline
\end{tabular}




\begin{tabular}{|c|c|c|c|}
\hline Country & Date & $\begin{array}{l}\text { DEFICIT } \\
\text { / GDP \% }\end{array}$ & AS/LI \% \\
\hline $\mathbf{L U}$ & $31 / 12 / 2013$ & 0.7153 & 251.4335 \\
\hline LU & $30 / 06 / 2014$ & 3.8050 & 243.5671 \\
\hline $\mathbf{L U}$ & $31 / 12 / 2014$ & 1.4697 & 240.3856 \\
\hline $\mathbf{L U}$ & $30 / 06 / 2015$ & 4.3043 & 244.4820 \\
\hline $\mathbf{L U}$ & $31 / 12 / 2015$ & 1.4462 & 249.4174 \\
\hline LV & $30 / 06 / 2004$ & -1.9583 & 134.1597 \\
\hline LV & $31 / 12 / 2004$ & -7.0366 & 125.8414 \\
\hline LV & $30 / 06 / 2005$ & 3.3098 & 140.5902 \\
\hline LV & $31 / 12 / 2005$ & -8.9997 & 129.6722 \\
\hline LV & $30 / 06 / 2006$ & 3.0086 & 134.1290 \\
\hline LV & $31 / 12 / 2006$ & -9.2170 & 121.8826 \\
\hline LV & $30 / 06 / 2007$ & 2.2672 & 128.8418 \\
\hline $\mathbf{L V}$ & $31 / 12 / 2007$ & -5.9506 & 122.1931 \\
\hline LV & $30 / 06 / 2008$ & 1.1484 & 112.6033 \\
\hline LV & $31 / 12 / 2008$ & -14.2968 & 105.9704 \\
\hline LV & $30 / 06 / 2009$ & -6.0786 & 99.9165 \\
\hline $\mathbf{L V}$ & $31 / 12 / 2009$ & -16.5436 & 88.4956 \\
\hline LV & $30 / 06 / 2010$ & -4.2240 & 87.9392 \\
\hline LV & $31 / 12 / 2010$ & -17.0820 & 76.9341 \\
\hline $\mathbf{L V}$ & $30 / 06 / 2011$ & 1.5458 & 76.8565 \\
\hline LV & $31 / 12 / 2011$ & -13.1482 & 71.4410 \\
\hline LV & $30 / 06 / 2012$ & 0.7537 & 72.1241 \\
\hline LV & $31 / 12 / 2012$ & -10.7165 & 74.8607 \\
\hline $\mathbf{L V}$ & $30 / 06 / 2013$ & 3.3460 & 75.2525 \\
\hline $\mathbf{L V}$ & $31 / 12 / 2013$ & -8.4184 & 71.8685 \\
\hline $\mathbf{L V}$ & $30 / 06 / 2014$ & 1.7717 & 72.7937 \\
\hline $\mathbf{L V}$ & $31 / 12 / 2014$ & -10.1353 & 68.3079 \\
\hline $\mathbf{L V}$ & $30 / 06 / 2015$ & 0.8728 & 64.2937 \\
\hline LV & $31 / 12 / 2015$ & -6.6259 & 62.7812 \\
\hline MT & $30 / 06 / 2004$ & -9.3529 & 39.8322 \\
\hline MT & $31 / 12 / 2004$ & 1.8703 & 38.9126 \\
\hline мT & $30 / 06 / 2005$ & -5.3425 & 38.8795 \\
\hline MT & $31 / 12 / 2005$ & 1.8294 & 41.8607 \\
\hline MT & $30 / 06 / 2006$ & -0.5470 & 39.6816 \\
\hline мT & $31 / 12 / 2006$ & -1.7132 & 37.2180 \\
\hline MT & $30 / 06 / 2007$ & -3.0887 & 40.7122 \\
\hline MT & $31 / 12 / 2007$ & -1.1361 & 40.1520 \\
\hline MT & $30 / 06 / 2008$ & -4.4928 & 39.7328 \\
\hline MT & $31 / 12 / 2008$ & -2.3706 & 35.0024 \\
\hline MT & $30 / 06 / 2009$ & -5.2818 & 38.8434 \\
\hline MT & $31 / 12 / 2009$ & -0.2406 & 36.5593 \\
\hline MT & $30 / 06 / 2010$ & -4.7992 & 38.1668 \\
\hline MT & $31 / 12 / 2010$ & -3.4644 & 37.4539 \\
\hline MT & $30 / 06 / 2011$ & -4.9531 & 40.3619 \\
\hline MT & $31 / 12 / 2011$ & -0.6026 & 38.6486 \\
\hline MT & $30 / 06 / 2012$ & -4.8581 & 43.6322 \\
\hline мT & $31 / 12 / 2012$ & -2.7804 & 42.5522 \\
\hline MT & $30 / 06 / 2013$ & -2.1712 & 44.4517 \\
\hline мT & $31 / 12 / 2013$ & 1.4688 & 42.8347 \\
\hline MT & $30 / 06 / 2014$ & -3.5322 & 45.2743 \\
\hline MT & $31 / 12 / 2014$ & 3.7616 & 38.5601 \\
\hline мT & $30 / 06 / 2015$ & -1.9030 & 39.2445 \\
\hline MT & $31 / 12 / 2015$ & 4.2108 & 37.9958 \\
\hline NL & $30 / 06 / 2010$ & -6.4808 & 60.6172 \\
\hline
\end{tabular}




\begin{tabular}{|c|c|c|c|}
\hline Country & Date & $\begin{array}{l}\text { DEFICIT } \\
\text { / GDP \% }\end{array}$ & AS/LI \% \\
\hline NL & $31 / 12 / 2010$ & -1.3281 & 57.9115 \\
\hline NL & $30 / 06 / 2011$ & -6.9527 & 57.9387 \\
\hline NL & $31 / 12 / 2011$ & -2.8195 & 54.1507 \\
\hline NL & $30 / 06 / 2012$ & -5.8882 & 57.1726 \\
\hline NL & $31 / 12 / 2012$ & -1.3224 & 54.9773 \\
\hline NL & $30 / 06 / 2013$ & -4.5919 & 56.6432 \\
\hline NL & $31 / 12 / 2013$ & -1.4928 & 55.0977 \\
\hline NL & $30 / 06 / 2014$ & -4.4129 & 54.7690 \\
\hline NL & $31 / 12 / 2014$ & 0.0093 & 53.4512 \\
\hline NL & $30 / 06 / 2015$ & -4.1787 & 53.5713 \\
\hline NL & $31 / 12 / 2015$ & 0.6571 & 52.7039 \\
\hline PL & $30 / 06 / 2004$ & -6.9757 & 55.1158 \\
\hline PL & $31 / 12 / 2004$ & -5.9220 & 60.3978 \\
\hline PL & $30 / 06 / 2005$ & -3.7176 & 60.0868 \\
\hline PL & $31 / 12 / 2005$ & -5.4854 & 61.2802 \\
\hline PL & $30 / 06 / 2006$ & -4.0591 & 63.3264 \\
\hline PL & $31 / 12 / 2006$ & -4.6602 & 63.4202 \\
\hline PL & $30 / 06 / 2007$ & -3.5679 & 67.4573 \\
\hline PL & $31 / 12 / 2007$ & -3.3555 & 70.8397 \\
\hline PL & $30 / 06 / 2008$ & -4.1171 & 73.4945 \\
\hline PL & $31 / 12 / 2008$ & -7.5529 & 71.7785 \\
\hline PL & $30 / 06 / 2009$ & -7.6504 & 69.2492 \\
\hline PL & $31 / 12 / 2009$ & -12.8871 & 65.3850 \\
\hline PL & $30 / 06 / 2010$ & -8.0387 & 61.9671 \\
\hline PL & $31 / 12 / 2010$ & -12.0368 & 58.4765 \\
\hline PL & $30 / 06 / 2011$ & -5.0688 & 56.6408 \\
\hline PL & $31 / 12 / 2011$ & -9.7484 & 54.0342 \\
\hline PL & $30 / 06 / 2012$ & -3.6329 & 55.8387 \\
\hline PL & $31 / 12 / 2012$ & -6.9754 & 52.2149 \\
\hline PL & $30 / 06 / 2013$ & -4.0871 & 50.9762 \\
\hline PL & $31 / 12 / 2013$ & -7.0999 & 48.7117 \\
\hline PL & $30 / 06 / 2014$ & -3.2320 & 50.3504 \\
\hline PL & $31 / 12 / 2014$ & -6.4788 & 47.9279 \\
\hline PL & $30 / 06 / 2015$ & -2.6992 & 48.9159 \\
\hline PL & $31 / 12 / 2015$ & -5.3555 & 47.2208 \\
\hline PT & $30 / 06 / 2004$ & -4.7723 & 38.0192 \\
\hline PT & $31 / 12 / 2004$ & -8.1638 & 37.0800 \\
\hline PT & $30 / 06 / 2005$ & -2.6461 & 35.7926 \\
\hline PT & $31 / 12 / 2005$ & -8.6226 & 36.4693 \\
\hline PT & $30 / 06 / 2006$ & -2.6582 & 37.3706 \\
\hline PT & $31 / 12 / 2006$ & -7.4636 & 37.8616 \\
\hline PT & $30 / 06 / 2007$ & -0.6234 & 37.1411 \\
\hline PT & $31 / 12 / 2007$ & -5.6364 & 36.9122 \\
\hline PT & $30 / 06 / 2008$ & -1.0387 & 37.6334 \\
\hline PT & $31 / 12 / 2008$ & -5.4514 & 36.1745 \\
\hline PT & $30 / 06 / 2009$ & -11.5561 & 36.4742 \\
\hline PT & $31 / 12 / 2009$ & -13.0260 & 33.9515 \\
\hline PT & $30 / 06 / 2010$ & -11.3692 & 36.8773 \\
\hline $\mathbf{P T}$ & $31 / 12 / 2010$ & -18.4889 & 38.9987 \\
\hline PT & $30 / 06 / 2011$ & -9.3609 & 43.3020 \\
\hline PT & $31 / 12 / 2011$ & -10.5893 & 47.1394 \\
\hline PT & $30 / 06 / 2012$ & -7.0973 & 44.1821 \\
\hline PT & $31 / 12 / 2012$ & -6.4368 & 43.3739 \\
\hline PT & $30 / 06 / 2013$ & -4.1164 & 41.9502 \\
\hline
\end{tabular}




\begin{tabular}{|c|c|c|c|}
\hline Country & Date & $\begin{array}{l}\text { DEFICIT } \\
\text { / GDP \% }\end{array}$ & AS/LI \% \\
\hline PT & $31 / 12 / 2013$ & -2.7700 & 40.6690 \\
\hline PT & $30 / 06 / 2014$ & -6.6231 & 40.0160 \\
\hline PT & $31 / 12 / 2014$ & -2.0345 & 40.9466 \\
\hline PT & $30 / 06 / 2015$ & -3.8905 & 40.1632 \\
\hline PT & $31 / 12 / 2015$ & -7.0866 & 40.2478 \\
\hline RO & $30 / 06 / 2007$ & 1.6719 & 174.4914 \\
\hline RO & $31 / 12 / 2007$ & -10.6238 & 144.2159 \\
\hline RO & $30 / 06 / 2008$ & -4.3368 & 129.6691 \\
\hline RO & $31 / 12 / 2008$ & -11.4360 & 152.3045 \\
\hline RO & $30 / 06 / 2009$ & -9.1190 & 124.1330 \\
\hline RO & $31 / 12 / 2009$ & -9.5327 & 114.0784 \\
\hline RO & $30 / 06 / 2010$ & -9.0664 & 99.2138 \\
\hline RO & $31 / 12 / 2010$ & -6.9065 & 82.1874 \\
\hline RO & $30 / 06 / 2011$ & -3.4428 & 80.7380 \\
\hline RO & $31 / 12 / 2011$ & -10.1932 & 66.9656 \\
\hline RO & $30 / 06 / 2012$ & -2.9633 & 63.4061 \\
\hline RO & $31 / 12 / 2012$ & -5.8582 & 65.7207 \\
\hline RO & $30 / 06 / 2013$ & -1.2385 & 64.8146 \\
\hline RO & $31 / 12 / 2013$ & -4.7823 & 61.2658 \\
\hline RO & $30 / 06 / 2014$ & -0.7220 & 62.8236 \\
\hline RO & $31 / 12 / 2014$ & -3.0428 & 62.4557 \\
\hline RO & $30 / 06 / 2015$ & 0.4008 & 64.6788 \\
\hline RO & $31 / 12 / 2015$ & -3.9013 & 63.5771 \\
\hline SE & $30 / 06 / 2004$ & 2.0968 & 88.8404 \\
\hline SE & $31 / 12 / 2004$ & -1.4558 & 92.1019 \\
\hline SE & $30 / 06 / 2005$ & 4.8259 & 95.0230 \\
\hline SE & $31 / 12 / 2005$ & -1.5672 & 99.1821 \\
\hline SE & $30 / 06 / 2006$ & 4.8852 & 106.9950 \\
\hline SE & $31 / 12 / 2006$ & -0.6397 & 115.5805 \\
\hline SE & $30 / 06 / 2007$ & 6.6415 & 123.7134 \\
\hline SE & $31 / 12 / 2007$ & 0.4609 & 125.3179 \\
\hline SE & $30 / 06 / 2008$ & 6.0085 & 124.8284 \\
\hline SE & $31 / 12 / 2008$ & -2.5832 & 115.1091 \\
\hline SE & $30 / 06 / 2009$ & 2.1861 & 123.4694 \\
\hline SE & $31 / 12 / 2009$ & -3.0049 & 125.7642 \\
\hline SE & $30 / 06 / 2010$ & 3.2018 & 128.3234 \\
\hline SE & $31 / 12 / 2010$ & -4.2359 & 130.6187 \\
\hline SE & $30 / 06 / 2011$ & 3.4656 & 142.8542 \\
\hline SE & $31 / 12 / 2011$ & -4.5056 & 133.4867 \\
\hline SE & $30 / 06 / 2012$ & 1.7138 & 136.7239 \\
\hline SE & $31 / 12 / 2012$ & -3.4385 & 136.4807 \\
\hline SE & $30 / 06 / 2013$ & 1.9259 & 134.1783 \\
\hline SE & $31 / 12 / 2013$ & -4.3464 & 134.2479 \\
\hline SE & $30 / 06 / 2014$ & 1.3710 & 133.5135 \\
\hline SE & $31 / 12 / 2014$ & -4.7283 & 129.9716 \\
\hline SE & $30 / 06 / 2015$ & 2.6503 & 131.2378 \\
\hline SE & $31 / 12 / 2015$ & -2.4784 & 129.9891 \\
\hline SI & $30 / 06 / 2004$ & -2.6162 & 119.9775 \\
\hline SI & $31 / 12 / 2004$ & -0.6572 & 121.9931 \\
\hline SI & $30 / 06 / 2005$ & -2.7678 & 119.9384 \\
\hline SI & $31 / 12 / 2005$ & 0.3072 & 119.6670 \\
\hline SI & $30 / 06 / 2006$ & -1.7957 & 120.5847 \\
\hline SI & $31 / 12 / 2006$ & 0.7258 & 122.8044 \\
\hline SI & $30 / 06 / 2007$ & -1.4108 & 133.5144 \\
\hline
\end{tabular}




\begin{tabular}{|c|c|c|c|}
\hline Country & Date & $\begin{array}{l}\text { DEFICIT } \\
\text { / GDP \% } \\
\end{array}$ & AS/LI \% \\
\hline SI & $31 / 12 / 2007$ & 1.1291 & 141.4996 \\
\hline SI & $30 / 06 / 2008$ & -1.4388 & 134.7117 \\
\hline SI & $31 / 12 / 2008$ & -2.8687 & 118.8862 \\
\hline SI & $30 / 06 / 2009$ & -5.6570 & 111.9367 \\
\hline SI & $31 / 12 / 2009$ & -5.8388 & 103.7873 \\
\hline SI & $30 / 06 / 2010$ & -7.4325 & 94.6482 \\
\hline SI & $31 / 12 / 2010$ & -3.5808 & 101.2964 \\
\hline SI & $30 / 06 / 2011$ & -7.5361 & 94.4647 \\
\hline SI & $31 / 12 / 2011$ & -4.5997 & 96.2251 \\
\hline SI & $30 / 06 / 2012$ & -3.8625 & 89.9945 \\
\hline SI & $31 / 12 / 2012$ & -3.4395 & 87.8542 \\
\hline SI & $30 / 06 / 2013$ & -5.6162 & 88.6717 \\
\hline SI & $31 / 12 / 2013$ & -40.4032 & 85.1375 \\
\hline SI & $30 / 06 / 2014$ & -3.0354 & 83.0547 \\
\hline SI & $31 / 12 / 2014$ & -8.7132 & 83.6371 \\
\hline SI & $30 / 06 / 2015$ & -2.7551 & 82.0888 \\
\hline SI & $31 / 12 / 2015$ & -3.9685 & 82.5068 \\
\hline SK & $31 / 12 / 2012$ & -6.8656 & 60.3614 \\
\hline SK & $30 / 06 / 2013$ & -1.5418 & 63.1434 \\
\hline SK & $31 / 12 / 2013$ & -4.6474 & 61.7156 \\
\hline SK & $30 / 06 / 2014$ & -2.0808 & 60.6680 \\
\hline SK & $31 / 12 / 2014$ & -3.9280 & 57.9057 \\
\hline SK & $30 / 06 / 2015$ & -2.3721 & 60.6025 \\
\hline SK & $31 / 12 / 2015$ & -5.2076 & 58.2115 \\
\hline
\end{tabular}

\section{Appendix D - Graphs of remaining 18 EU Member States}
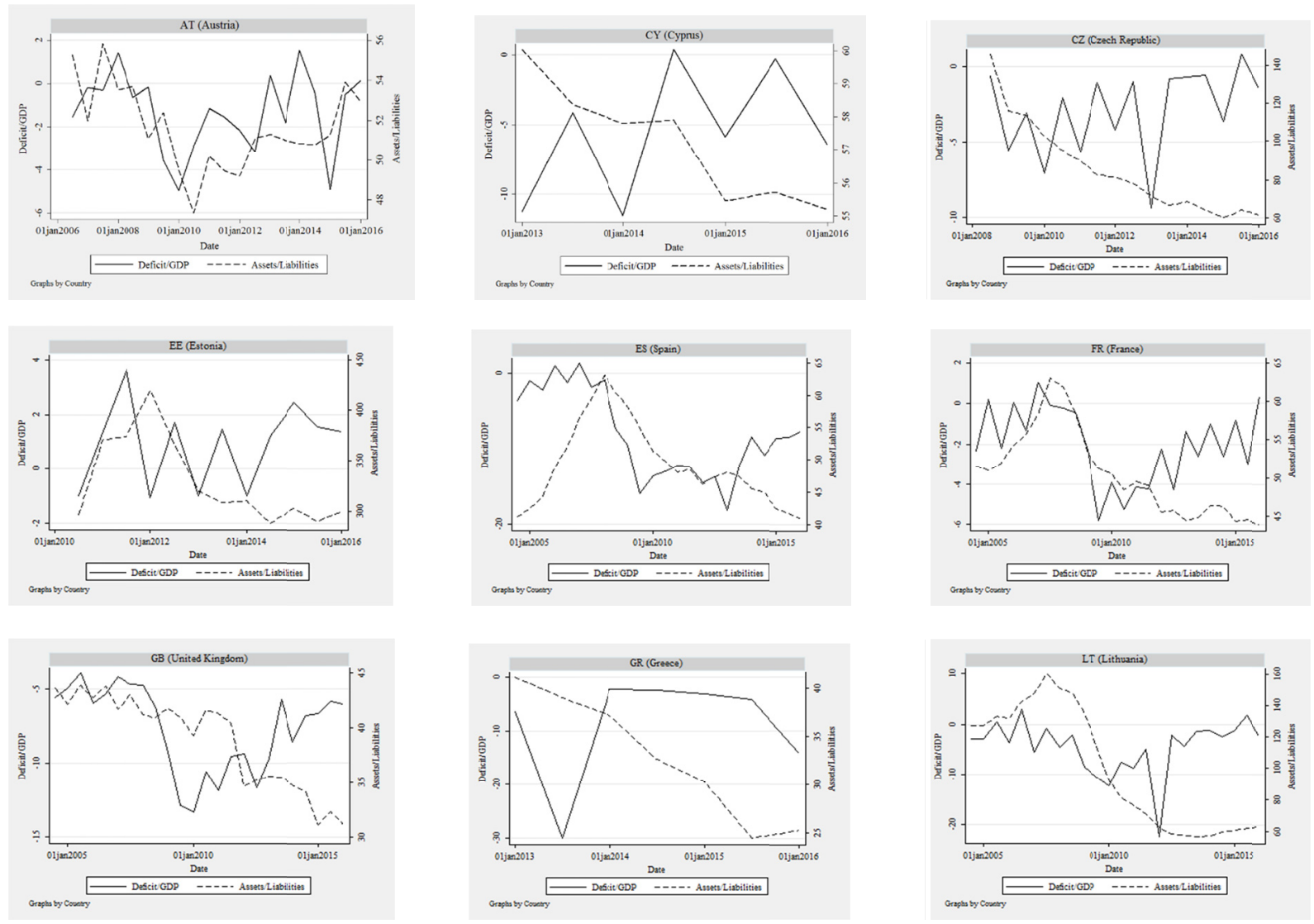

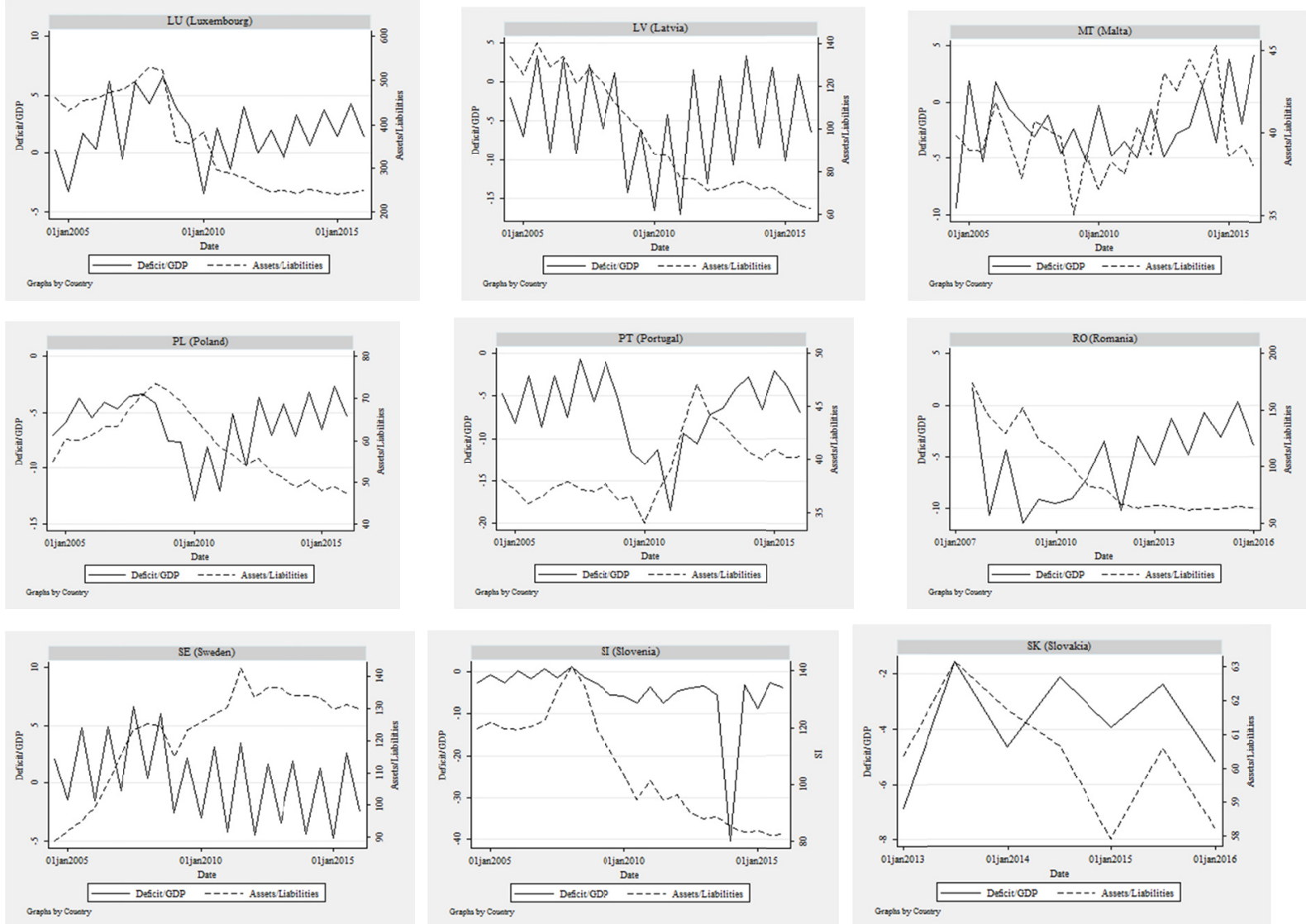

Figures 4. Descriptive statistics

\section{Note}

Note 1 . The model and the graphs are computed with STATA 13.

\section{Copyrights}

Copyright for this article is retained by the author(s), with first publication rights granted to the journal.

This is an open-access article distributed under the terms and conditions of the Creative Commons Attribution license (http://creativecommons.org/licenses/by/4.0/). 